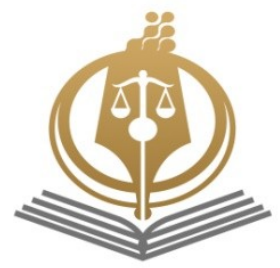

Interdisciplinary Legal Research

Oct 2020, 1(3): 84-101

Available online on: www. ilrjournal.ir

e-ISSN: 2717-1795

\title{
The Universal Declaration of Human Rights from the Standpoint of Classic Philosophical Schools of International Law
}

Ebrahim Yaghouti ${ }^{1 *}$ Farid Beiranvand ${ }^{2}$

Received:
23 Aug 2020
Revised:
18 Sep 2020
Accepted:
24 Sep 2020
Available Online:
01 Oct 2020

Keywords:

Philosophical Schools,

Human Rights, Natural Rights, Positivistic Rights, Utilitarianism.
Background and Aim: Science of law is an instrument to regulate the relationships between persons and subjects. Doubtlessly, today human persons as the main subjects of law also are considered as the ultimate intent of law; as the result, human rights have a very important status in the governing legal order.

Materials and Methods: This is a descriptive Study.

Ethical Considerations: All ethical considerations as well as authenticity of the texts have been observed.

Findings: The very concept of human rights by a reading different from the current one, have been existed since the early stage of birth of philosophical thoughts; but, through the time and by the introduction of concepts such as "government", "sovereignty", "law", and "rule of law" the way of human right entering the space of implementation undergone basic evolutions.

Conclusion: In the text of the Universal Declaration of Human Rights, one may see how schools of philosophy, law, and politics have been crystalized in it.

1* Assistant Professor, Jurisprudence and Basics of Islamic Law Department, Faculty of Literature and Humanities, Tehran Centeral Branch, Islamic Azad University, Tehran, Iran. (Corresponding Author)

Email: Yaghouti2010@yahoo.com Phone: +982144600200

${ }^{2}$ PhD of General International Law, Faculty of Literature and Humanities, Tehran Centeral Branch, Islamic Azad University, Tehran, Iran.

Please Cite This Article As: Yaghouti, E \& Beiranvand, F (2020). "The Universal Declaration of Human Rights from the Standpoint of Classic Philosophical Schools of International Law". Interdisciplinary Legal Research, 1 (3): 84-101. 
مقاله يزوهشى

(1) (1-1) (صفخات (1)

\section{اعلاميه جهانى حقوق بشر از منظر مكاتب فلسفى كلاسيك حقوق بينالمللى}

\section{ابراهيم ياقوتى '، فريد بيرانوند'}

ا. استاديار، كروه فقه و مبانى حقوق اسلامى، دانشكده ادبيات و علوم انسانى، واحد تهران مركزى، دانشگاه آزاد اسلامى، تهران، ايران. Email: Yaghouti2010@yahoo.com (نويسنده مسؤول)

ז. دكترى حقوق بين الملل عمومى، دانشكده ادييات و علوم انسانى، واحد تهران مركزى، دانشخاه آزاد اسلامى، تهران، ايران. دريافت:

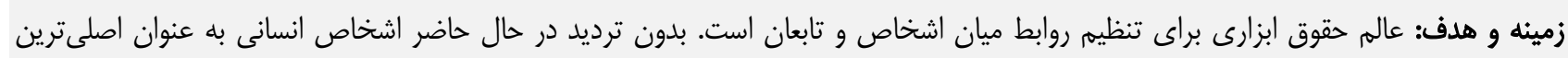

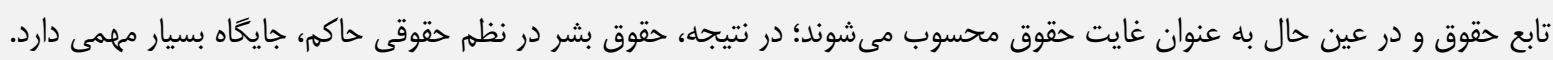

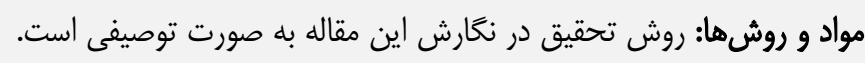

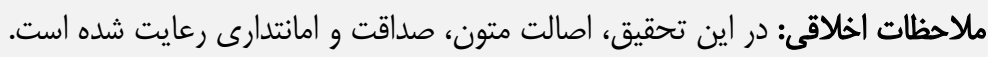

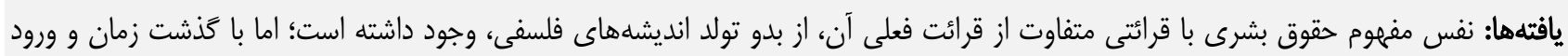

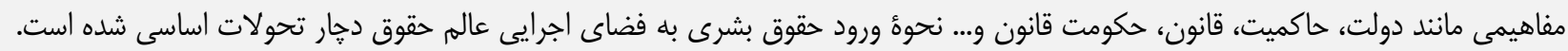

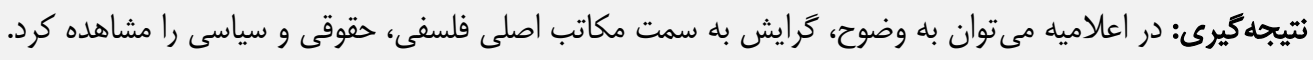
كلمات كليدى: مكاتب فلسفى، حقوق بشرى، حقوق طبيعى، حقوق يوزيتيويستى، فايدهر ايى. 
1997: 730 يونانىها اين قانون جهانشمول را كه از طبيعت خاص بشر سرجشمه مى گیرد، لاقانون طبيعته يا لاحقوق طبيعى" نام نهادند. ارسطو در تعريف حقوق طبيعى مى گويد:

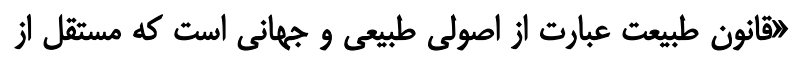

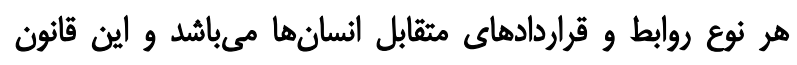
Hakonssen, ) بايستى از طرف همه انسانها شناسايى شود.

(1996: 20; Hochstrasser: 2000: 30 در اينجا بايد اضافه كنيم كه قوانين هلنها' از دو قسمت تشكيل مىشد. يك قسمت قوانين قراردادى بود كه براى تنظيم روابط ملى و بينالمللى خود تصويب كرده بودند؛ قسمت ديخر، مجموعهاى از عرفها بود كه در طول زمان به صورت رسم بوجود آمده و در ميان آنها متداول بود. فلاسفهُ يونان معتقد بودند كه عرفهاى يونان از حقوق طبيعى سرجشمه كرفتهاند و حقوق طبيعى مافوق حقوق موضوعه مى باشد. اما در عين حال بايد دانست كه ادبيات فلسفى و حقوقى يونان باستان درباره محتويات حقوق طبيعى گنخ و مبهم است. دانشمندان يونانى به اين سؤال كه بالاخره اين حقوق طبيعى

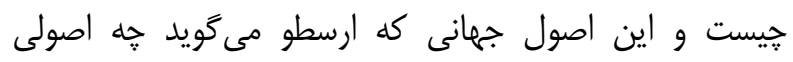

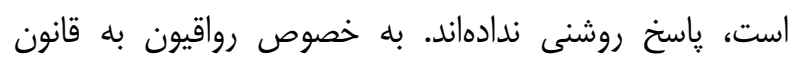
طبيعى جنبة متافيزيك مىدادند. در ترتيب ورود به تاريخ، بعد از متفكرين يونانى، نوبت به مانه فلاسفه و علماى حقوق روم رسيد كه انديشه و محتويات حقوق طبيعى ‘ را برورش دهند. متفكرينى مانند سيسرون، " اليين،

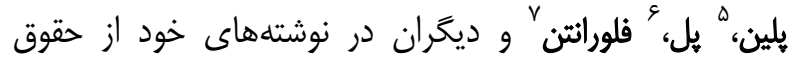
طبيعى سخن به ميان آوردند و حتى آن را شرح و بستى بيشتر

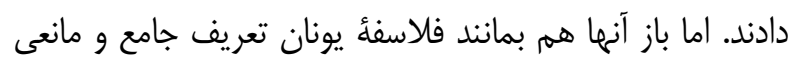
از حقوق طبيعى به دست ندادند و واحدهاى آن را معرفى لنى بهن نكردند و خلاصه محتويات اين حقوق را مشخص نساختند. بايد

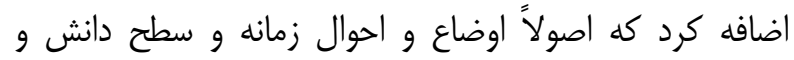

\footnotetext{
1 - Hellenes

2 - Jus naturale

3 - Ciceron

4 - Ulpien

5 - Pline

${ }^{6}$ - Paul

${ }^{7}$ - Florentin
}

\section{مقدمه}

ا- بيان موضوع: حقوق آن جيزى است كه براى رشد بشر و ظهور شخصيت او در جامعه الزامى است. با توجه به معيارهاى مربوط به حقوق بنيادين انسان در جهان امروز، انسانهاى بدون حقوق تضمين شده كه سرنوشتشان مطلقاً منوط به ميل و هوس مقامى غيرمسؤول باشد، بردمانى هستند فاقد اراده، متعلق به اعصار عتيقه و در جايخاه (McCrudden, 2015:6) بهائم. جامعلاى كه از اين نوع انسانها تشكيل شده باشد نيز جامعهاى است در همان جايگاه افراد خود كه شايستخى زيستن در ميان ملل متجدد كنونى را ندارد.

r- بيشينه موضوع: نفس انديشأ 》حقوق بشرى" فارغ از قرائتهاى متفاوت آن، داراى عمرى به بلنداى عمر انسان

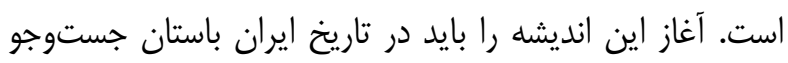

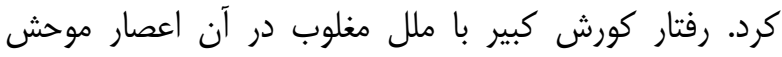
تاريخ (•Dه تا • •ه قبل از ميلاد) و اعلاميه وى خطاب به

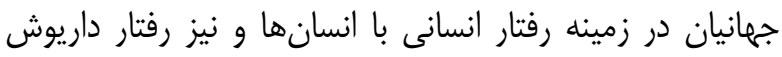

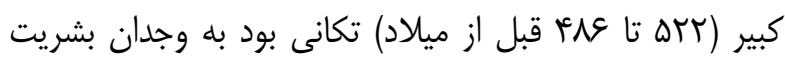

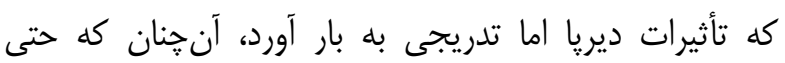

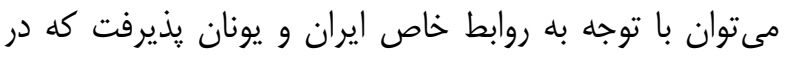
حوزههاى فلسفى آن مردم، به خصوص رواقيون، اثر كرده است.

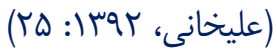
ذهن فلاسفة يونان، در طى مراحل مختلف تكامل فكرى،

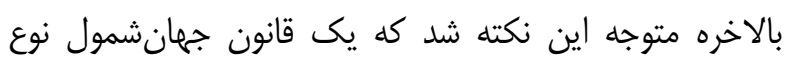
بشر وجود دارد كه براى همه انسانها صرفاً از جهت انسان جهان بودن الزامآور است. به اعتقاد فلاسفه مذكور اين قانون قدرت اجرايى خود را نه از توافقهاى بين افراد يا دولتها بلكه قدرت الزامى خود را از طبيعت خاص بشر مى گيرد. آنها خنين اعتقاد داشتند كه انسان در زندگى اجتماعى نبايستى تنها تابع

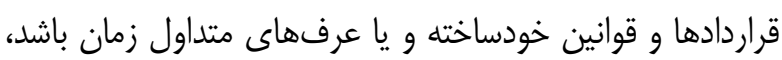
بلكه مافوق اين قوانين و عرفها قانونى وجود دارد و بشر به اين دليل كه بشر است بايد در هر زمان متوجه اين قانون باشد و از آن نيز به مانند قوانين موضوعه اطاعت كند. ( Zuckert, 
معقول بشر سازكارى نداشته باشد، آن عمل شر و خلاف

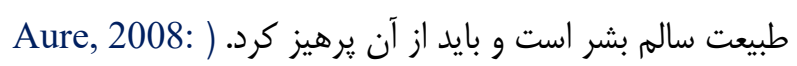

بعد از كروسيوس، ولف آلمانى و امر دوواتل سوئيسى و سبس منتسكيوى فرانسوى و ديخران انديشأ حقوق طبيعى را به وله صورت مكتبى بالغ و منسجم درآوردند و محتويات آن را با

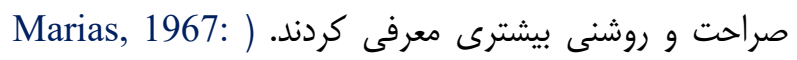
680) از جمله اصول حقوق طبيعى كه در عرض حدود يكصد و مونى ينجاه سال به وسيلة اين انديشمندان معرفى شد مىتوان به به اصول ذيل اشاره كرد: الف. حق حيات فرد در جامعه ملى و حق حيات هر دولت (اعم از كوخى يا بزرگ) در جامعه بينالمللى؛

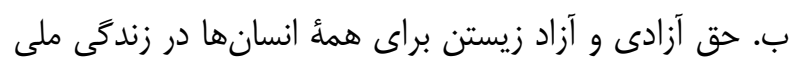

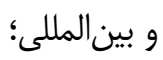
ج. حق تساوى افراد در جامعه ملى و حق تساوى دولتها اعم

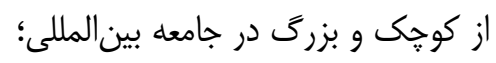

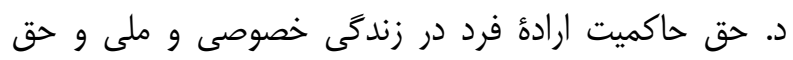

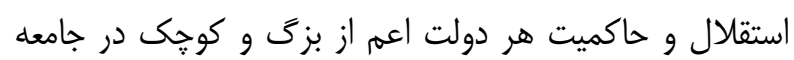

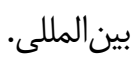
در اينجا بايد به ياد آورد كه تمام تحولات سياسى مترقيانه كه

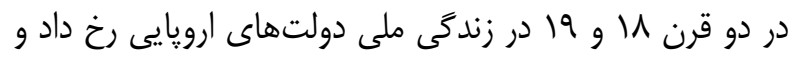
بعد به ساير قارهها نيز صادر شد، بر مبناى همين اصول (يا به تعبيرى حقوق) است كه به قلم متفكرين طرفدار مكتب حقوق طبيعى در ذهن بشر كاشته شد. در دنيايى كه در طى جند هزار سال از يك طرف بـ قدرتمندان

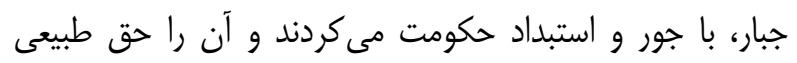
خود مى دانستند و از طرف ديگر كلههاى انسانى مطيعانه جور مى كشيدند و قربانى مىشدند و اين را سرنوشت محتوم خود

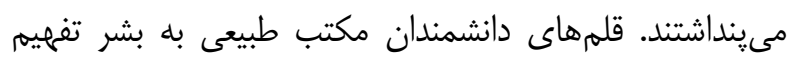

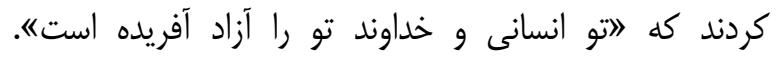

(Goodman, 2004: 630)
بينش مردم زمان، آماده فكر كردن و توجه كردن به حقوق

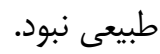
بعد از تجزيه اميراطورى روم بزرگ به دو اميراطورى شرقى و

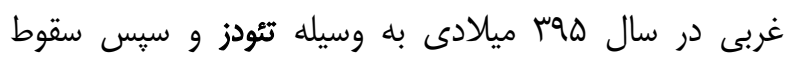
امير اطورى روم غربى به دست قبايل نيمه وحشى زرمن در سال Vو أغيلادى، دوران قرون وسطى و عصر فئوداليزم در ارويا

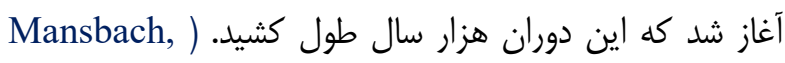

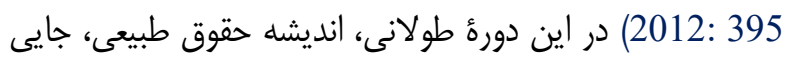
براى رشد و توسعه نيافت. در اين دوره كاهكاهى آباى كليسا براى تقويت فلسفه دينى خود به حقوق طبيعى مراجعه مى كردند. آنها نام حقوق طبيعى را در نوشتههاى خود به حقوق الهى برمى گردانيدند. در ميان روحانيان دين مسيح ويتورياى

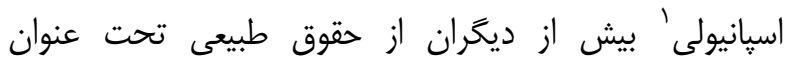
"اخلاق جهانى" و "اعقل طبيعى" بحث به ميان آورده است. (Tierney, 1997: 1100; Brett, 1997: 97 ) بعد از سبرى شدن عصر فئوداليسم و شروع عصر جديد، انديشه

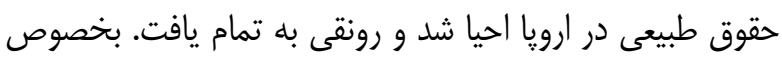

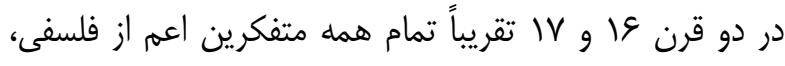
حقوقى و يا سياسى، وابسته به مكتب حقوق طبيعى بودند. در همين دوره بود كه هوكو كروسيوس هلندى ظهور كرد و از حقوق طبيعى، تعريفى مدرن و جامع به دست داد. در حقيقت كروسيوس نه تنها حقوق طبيعى عصر يونانيان را زنده كرد؛ بلكه تنظيهم و تدوين نمود. او معتقد است كه حقوق طبيعى، فرمان عقل سليم است كه نشان مىدهد يك عمل به علت مط مطابقت

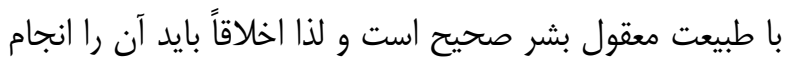
داد و از طرف خداوند مؤلف طبيعت نيز دست زدن به آن ممنوع شده است. (Hugo, 2000: 19) كروسيوس با وضع اين تعريف زيبا و در عين حال جامع و مانع

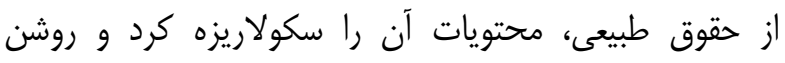
ساخت. طبق اين تعريف، خه در زندگى فردى و خه ملى ملى و خها

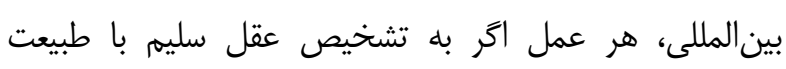

\footnotetext{
1 - Francisco de Vitoria
} 
حكومت توتاليتر مقتدر در جهان ظهور كرد، (مانند حكومت

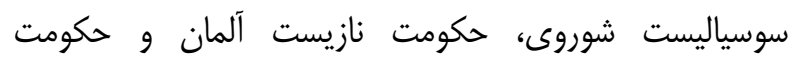

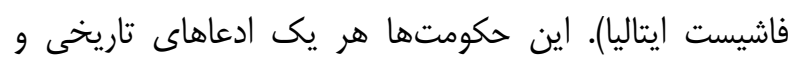
فلسفع سياسى خود را داشت كه در آنها دموكراسى و حقوق و أزادىهاى فردى جايى نداشت. بنابراين يادزهر آنجنان توتاليتريسمى، حقوق طبيعى و معانى و محتواى آن بود، زيرا

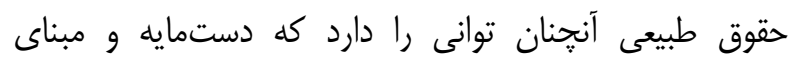

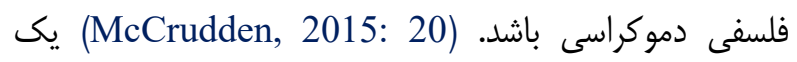

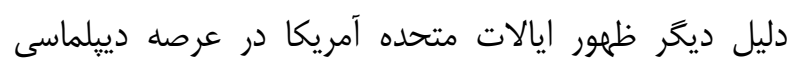
جهان به عنوان بازيخر شماره يك بود كه بررسى آن خارج از حوصلئ مختصر حاضر است. امروزه حقوق بشر، حقوق مادى قانونى تضمين شده فرد انسان در سراسر جامعه بشرى است. انديشٔ حقوق بشرى تقريباً در

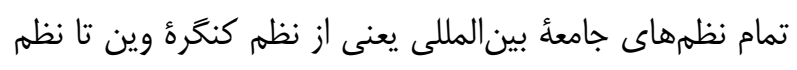

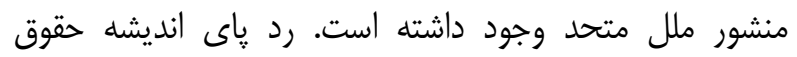
بشرى را مىتوان از مقدمٔ منشور ملل متحد تا برخى مواد (به منه طور خاص شوراى اقتصادى، اجتماعى) مشاهده كرد.

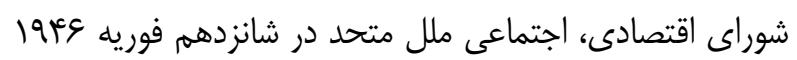
جند نفر را به عنوان اعضاى كميسيون هستهاى حقوق بشر مانى انتخاب كرد. اين اشخاص با توجه به صلاحيتهاى شخصى و

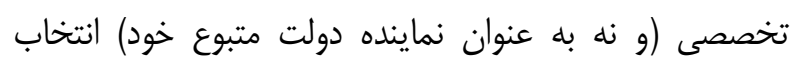
شدند. اختلافات زيادى بر سر مسائل مهرم از جمله مسائل

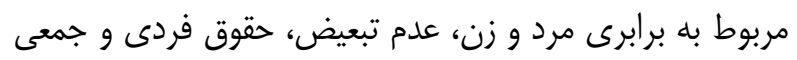
و... كه ريشه در ديدكاههاى ايدئولوزيكى، اقصادى، اجتماعى و ورئه

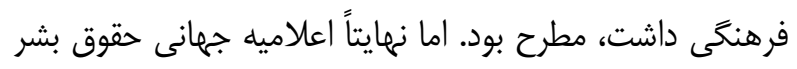
مشتمل بر يك مقدمه و •r ماده در روز دهم دسامبر سال

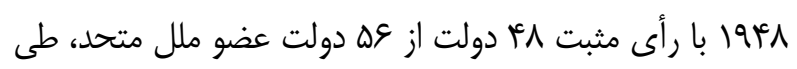
قطعنامه شماره TIV به تصويب رسيد. اين اعلاميه بدون رأى مثلى مخالف اما با رأى ممتنع ^ دولت همراه بود، كه آراء ممتنع عبارت بودند از: بيلاروس، جكسلواكى، لرهستان، عربستان

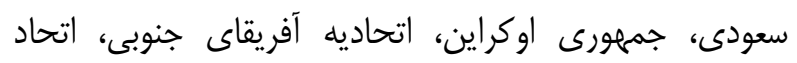
جماهير شوروى و يوگسلاوى. (Bahalla, 1991: 25)
نتيجه عملى اين موعظه در زندگى ملى به صورت خلع

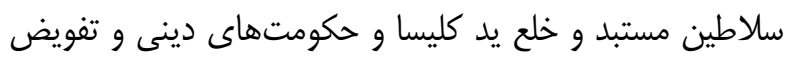
قدرت حكمرانى به ملتها و استقرار حكومتهاى ملى و نظام

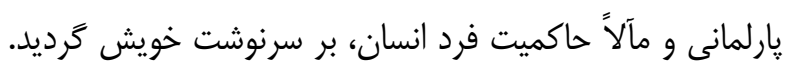
در قرن نوزدهم كشورهاى ارويايى به تسخير قاره آسيا يرداختند و به تدريج سرزمينهاى متعدد و اقوام و ملل گوناگونى راني مستعمره خود ساختند. در اين مقطع زمانى، عدهاى از حقوقدانان و متفكرين وابسته به منافع استعمارى دولتهاى خود، محتويات حقوق طبيعى را مخالف هدفهاى استعمارى مىديدند. زيرا

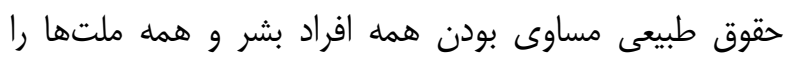
توصيه مى كرد. حقوق طبيعى از حق حيات و آزادى همه ملتها

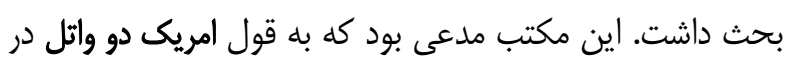

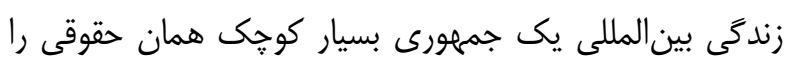

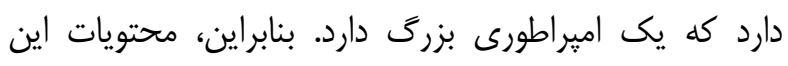
مكتب با هدفهاى استعمارى سازكار نبود و لذا حقوقدانان

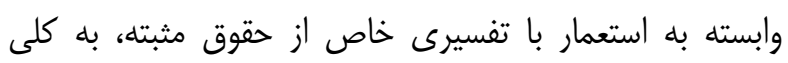

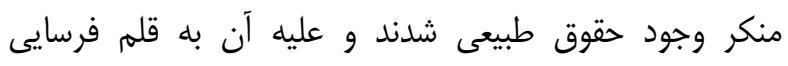
يرداختند و در نتيجه در قرن نوزدهم انديشأ حقوق طبيعى را به لهديه

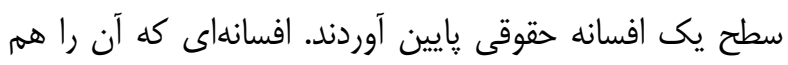
غير لازم و هم ناكافى جلوه مى دادند. در عصر استعمار، دكترينهاى سياسى متعددى مانند مكتب

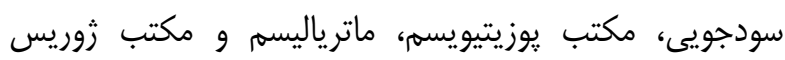
يرودانس تاريخى، به لحاظ شرايط ويزه زمان، طرفداران زيادى مئي

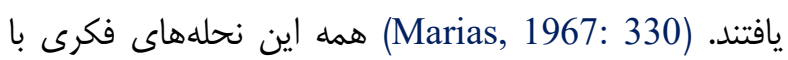
حقوق طبيعى كه توجه عميق به گوهر انسانيت و فرد انسان

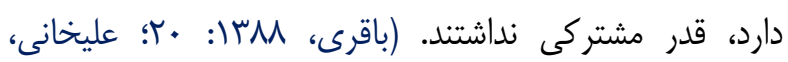

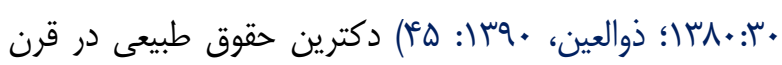
بيستم به طرز ديگرى و با كمى تغيير لفظى در نام و

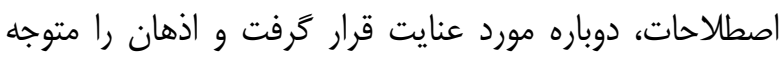
خود ساخت. حقوق طبيعى در اين مرحله كاهى لاحقوق طبيعى

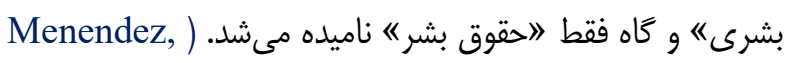
2006: 13; Spaak, 2014: 25 مجدد، متعدد است. از جمله يكى اينكه در قرن بيستم هند 
حقوق بشر تضمين و اجرا مى گردد، حكومت قانون است. حكومت قانون بدون وجود ابزارى به نام دولت و حاكميت اساساً

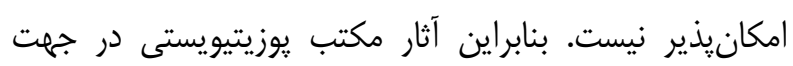

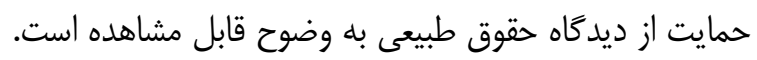
در عبارت لازاز آنجا كه اساساً لازم است توسعه روابط دوسئ دوستانه

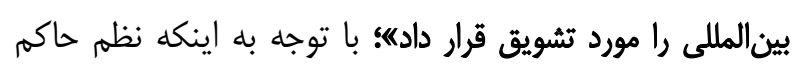
در فضاى سال 1941 ميلادى يك نظم دولتمحور بوده است، مقصود از "توسعه روابط دوستانه بينالمللى" توسعه روابط ميان

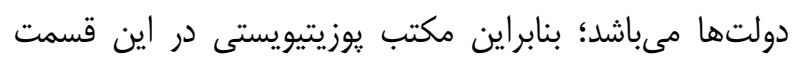

خودنمايى مى كند. (Morsink, 1999: 185) در عبارت لاز آنجا كه مردم ملل متحده ايمان خود را به حقوق

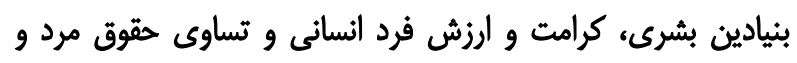
زن مجدداً در منشور، اعلام كردهاند و تصميم راسخ كرفتهاند كه به فيه ييشرفت اجتماعى كمى كنند و در محيطى آزاد، وضع زندكى بهترى

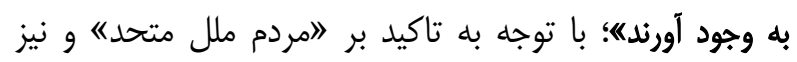
"حقوق بنيادين بشرى، كرامت و ارزش فرد انسانى" تبلور مكتب طبيعت گرايى قابل لمس است. همجنين تاكيد بر نظمه

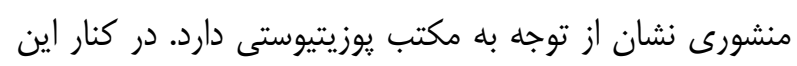

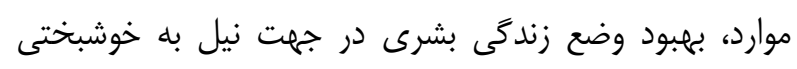

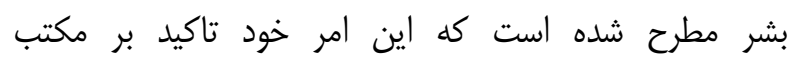
فايدهر ايى را افاده مى كند. در عبارت الاز آنجا كه حسن تفاهم مشتركى نسبت به اين حقوق و

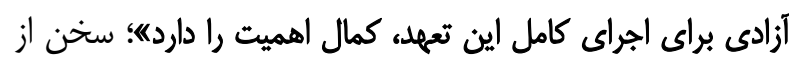

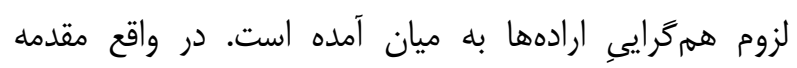
تضمين اجراى حقوق و آزادىهاى مندرج در اعلاميه به خواست و همكارى نهاد دولت بازمى گردد؛ بنابراين در اينجا

$$
\text { مكتب يوزيتيويستى خودنمايى مى كند. }
$$

در عبارت "امجمع عمومى اين اعلاميه جهانى حقوق بشر را آرمان

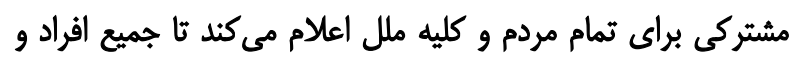

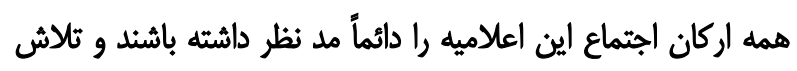
كنند كه به وسيلهى تعليم و تربيت، احترام به اين حقوق و آزادىها

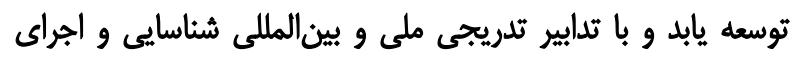

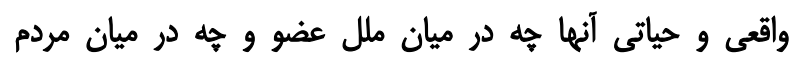

اعلاميه جهانى حقوق بشرى بدون ترديد از نظر ماهيت حقوقى

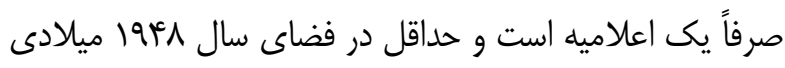
هيج گونه الزامى براى دولتها ايجاد نمى كند. برخى نويسندًان

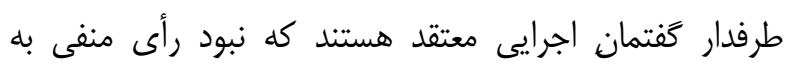
اعلاميه جهانى حقوق بشرى به دليل اعلاميه بودن آن است،

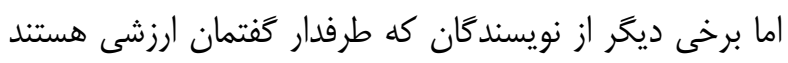
جنين استدلال مى كنند كه فقدان رأى منفى به دليل اين است

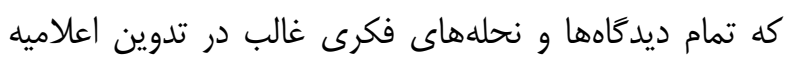
مشاركت داشتهاند. فارغ از اين بحث (كه در نتيجه گيرى بهاه بدان خواهيم يرداخت) در ادامه به بررسى مقدمه و مواد اعلامين بحت دئه جهانى حقوق بشرى مىيردازيه. r- روش تحقيق: اين يزوهش بصورت توصيفى است. بحث و نظر 1- مقدمه اعلاميه در عبارت الاز آنجا كه شناسايى حيثيت و كرامت ذاتى تمام اعضاى خانواده بشرى و حقوق برابر و سلبنابذير آنان اساس آزادى، عدالت

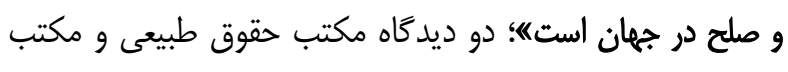

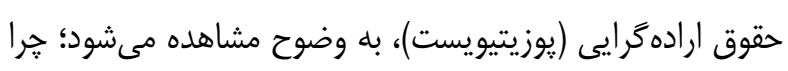

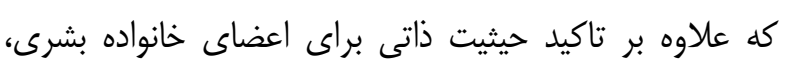

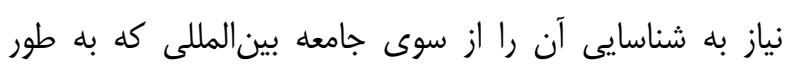
خاص در اينجا دولتها مىباشند، مورد تاكيد قرار مى دهد.

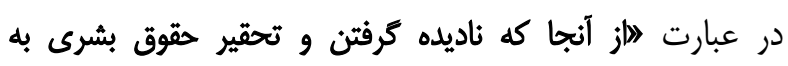
اقدامات وحشيانهاى انجاميده است كه وجدان بشر را بر آشفتهاند و

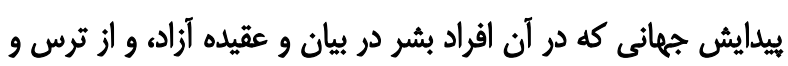

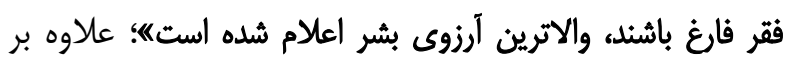

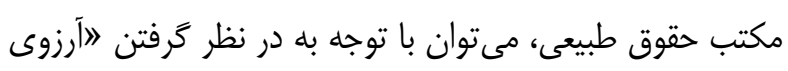

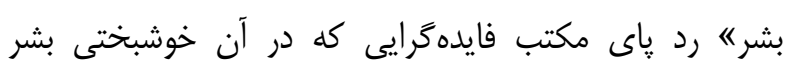

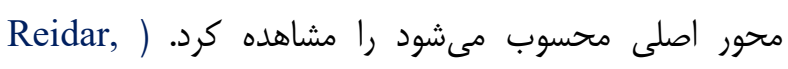

(2017: 130

در عبارت لااز آنجا كه ضرورى است كه از حقوق بشر با حكومت

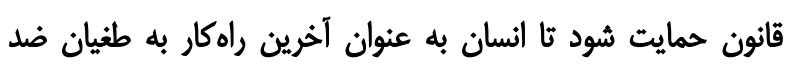

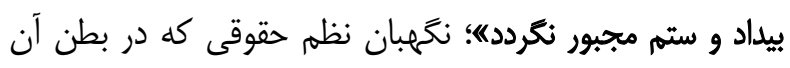


كليهى آزادىهايى كه در اعلاميهى حاضر ذكر شده است،

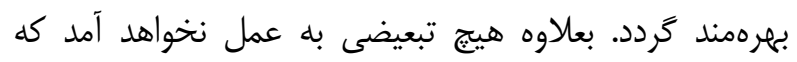
مبتنى بر وضع سياسى، ادارى و قضايى يا بينالملى دولت يا

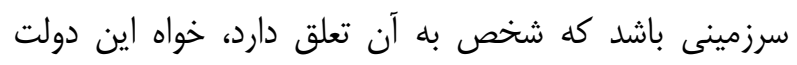

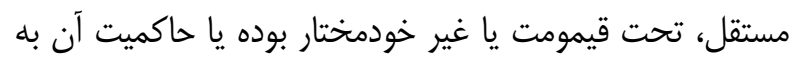

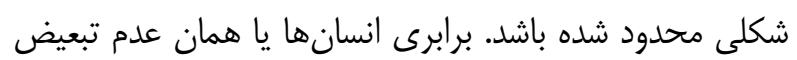
در دو محور مورد بحث قرار مى گيرد، يكى از لحاظ ارزش و كرامت ذاتي انسان، و ديخرى از لحاظ حقوقى كه به اعتبار

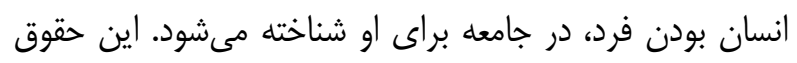
جدا از طبيعت انسان نيستند. در اين ماده مكتب حقوق طبيعى بـى بردي در دو سطح خود را نشان داده است. در قسمت اول اين ماده، عدم تبعيض و برابرى افراد انسانى مدنظر قرار گرفته است و در قسمت دوم برابرى دولتها، صد البته از منظر حقوقى، مورد

توجه قرار كرفته است. (Tomuschat, 2003:60) در ماده سوم از اعلاميه حق زندگَى، آزادى و امنيت شخصى

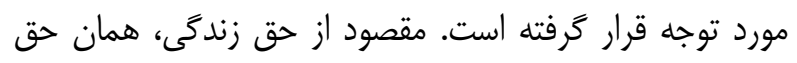
حيات است كه پايه و اساس تمام حقوق انسانى است؛ زيرا همه حقوق وابسته به وجود خود انسان است و بدون وجود انسان هيج حقى براى هيج فردى معنا و مفهومى ندارد. حق حيات از حقوق ذاتي شخص انسان است. مقصود از آزادى شخصى اين لئ

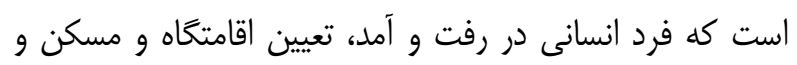
در زندگى و حريم خصوصى خود آزاد باشد. مقصود از امنيت

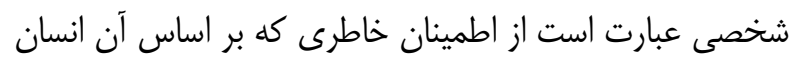

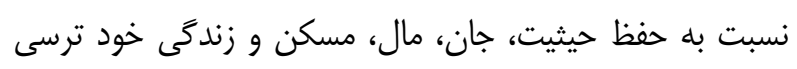

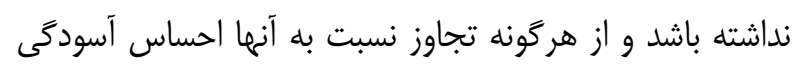
خاطر بنمايد. بارى، اين سه حق به عنوان سه اصل اصل مبنايي

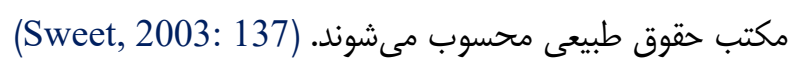

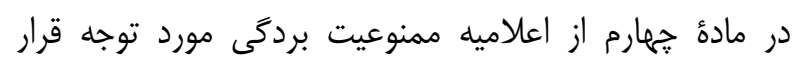

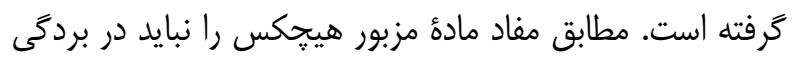

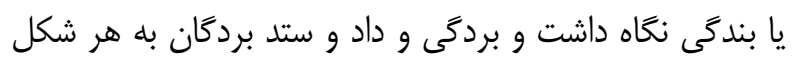
كه باشد ممنوع است. بدون ترديد در برههاى از تاريخ (تقريبا يكصد سال ييش)، نهاد بردگى در بسيارى از دولتهاى جهان بهان

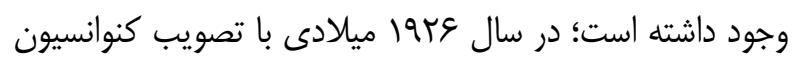

دولتهاى عضو و جه در ميان اتباع بيكانه مقيم در قلمرو دولتهاى

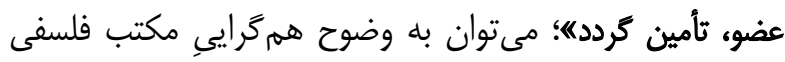

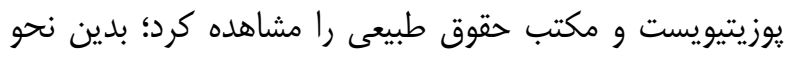
كه آرمان مشترى تلقى كردن حقوق بشرى و نيز قائل شدن وصف جهانى براى حقوق بشرى و عدم تفكيك ميان اتباع و غير اتباع، نماد بارٍٍ مكتب حقوق طبيعى مىباشد. در كنار اين امر، لزوم تلاشي مداوم توسط تمام اركان اجتماع، كه دولت نيز ليز يكى از آن است، در جهت احترام و توسعه حقوق بشرى و نيز

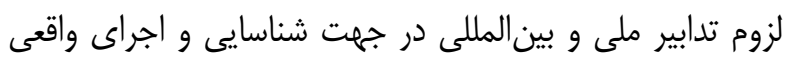
حقوق بشرى توسط دولتها، نشان دهنده تاثير مكتب

يوزيتيوستى مىباشد. (Verde Garrido et al, 2020:

\section{r- مواد اعلاميه}

\section{r-1- اصول و حقوق انسانى}

r-1-1- اصل آزادى بشر: در اولين ماده از اعلاميه به اصل اصل آزادى افراد بشر اشاره شده است. مطابق مفاد مادهٔ مزبور، تمام

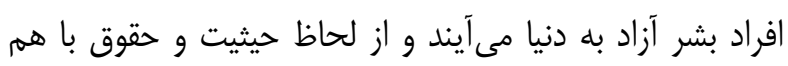

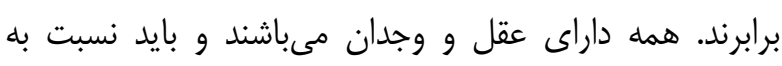

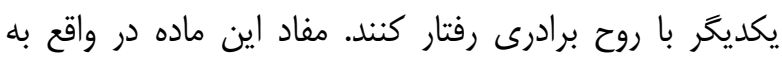
عنوان نماد اين گَزاره مسلمِ حقوقى است كه مفهوم حقوق بشر، يا حقوق طبيعى بشرى، ترجمان مفهوم حقوق طبيعى در قرن

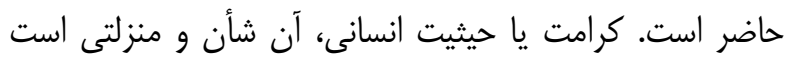
كه انسان فراتر از غرايض و به واسطه صفت انسانيت در خود

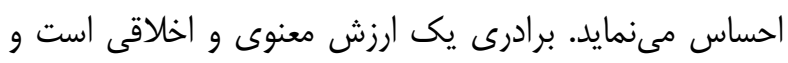

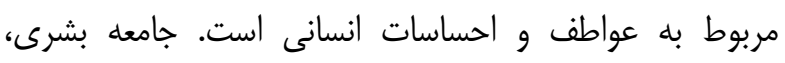
مجموع افرادى كه مانند اشياء و كالا در كنار يكديگر قرار كرفته باشند نيست؛ اين عواطف و مودت و روح برادرى و تعاون است كه ييوند دهنده اخلاقى انسانها به يكديخر مىباشند.

(Wodon, 2015: 112) در ماده دوم از اعلاميه به اصل برابرى و عدم تبعيض اشاره

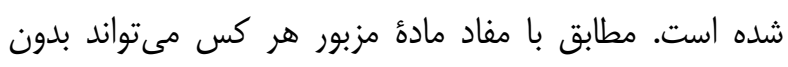

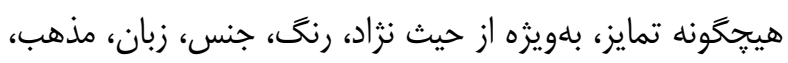
عقيده سياسى يا هر نوع عقيده ديخر و همجنين مليت، وضع

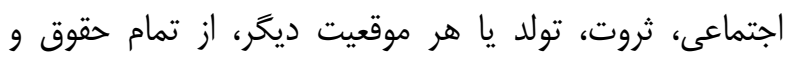


قانون در موارد نقض اعلاميه نشان از گرايش به مكتب حقوق طبيعى دارد. در كنار اين امر، توجه به نهاد قانون نيز لازم است،

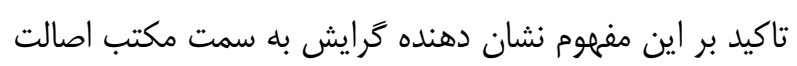

قاعده مىباشد. (Zolo, 2010: 560) حق بر دادخواهى در ماده هشتم از اعلاميه مورد توجه قرار كرفته است. به موجب مفاد ماده مزبور، هر شخص حق جبران

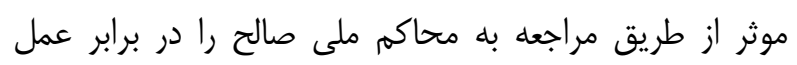
متجاوزانه نسبت به حقوق بنيادينى كه توسط قانون اساسى يا

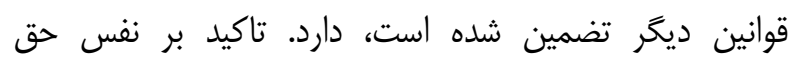

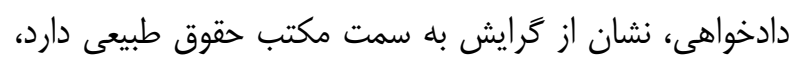

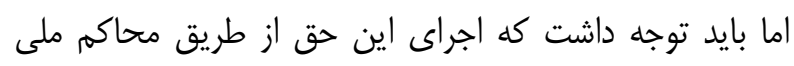

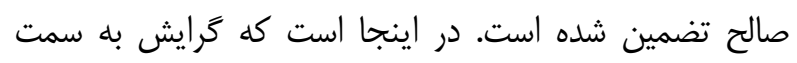
مكتب يوزيتيويستى نيز ديده مىشود. در واقع در اين ماده،

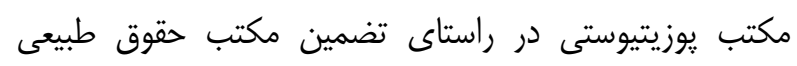

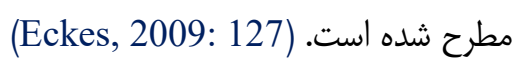
حق بر رهايى از حبس خودسرانه به صورت مطلق در ماده نهم از اعلاميه مورد توجه قرار گرفته است. به موجب ماده مزبور، هيجِس را نبايد خودسرانه، توقيف، حبس يا تبعيد كرد. مفاد اين ماده به يكى از حقوق بنيادين انسانى يعنى آزادى تاكيد

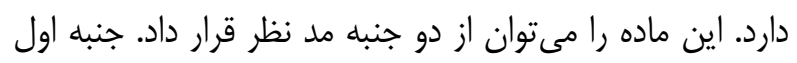

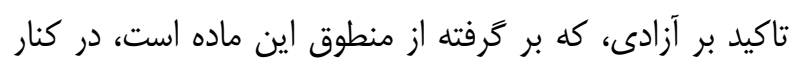
جنبه دوم كه مفهوم مخالف ماده يعنى تاكيد بر قانونَّايى

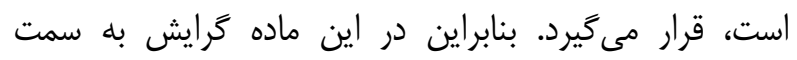
مكتب حقوق طبيعى و نيز مكتب اصالت قاعده را مىتوان

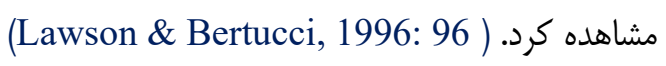
حق بر دادرسى عادلانه و مصاديق آن در ماده دهم از اعلاميه

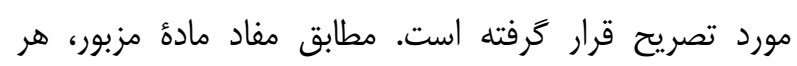

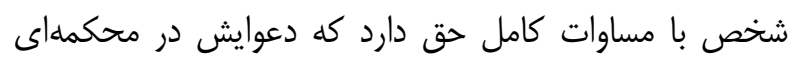

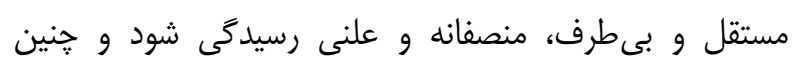
محكمهاى درباره حقوق و الزامات وى، يا هر اتهام كيفرى كه متوجه وى شده باشد، تصميم بخيرد. نفس حق رسيدگى

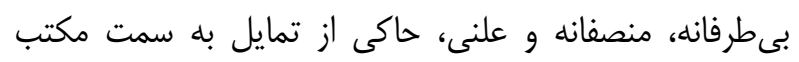

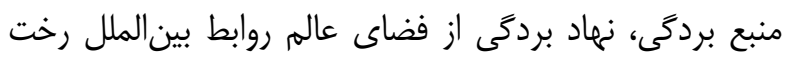

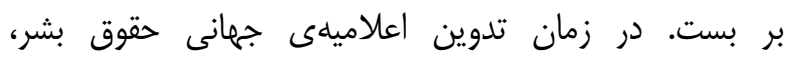

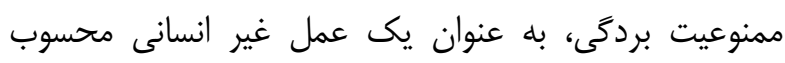

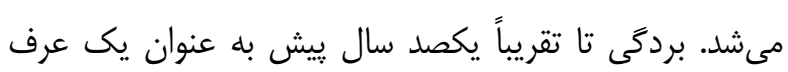

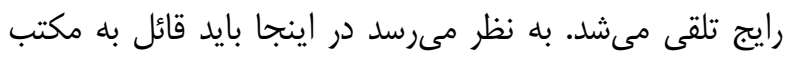

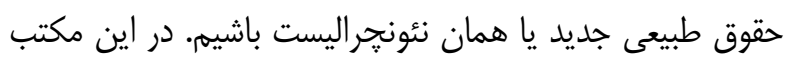

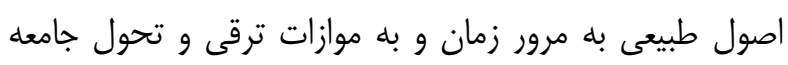

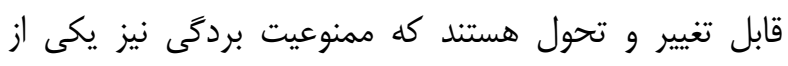
مصاديق بارز اين اصول مىباشد. (Morsink, 1999: 103) در ماده ينجمم از اعلاميه ممنوعيت شكنجه مورد توجه قرار

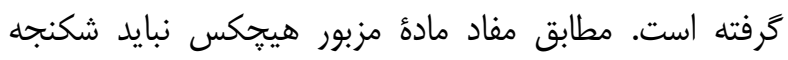

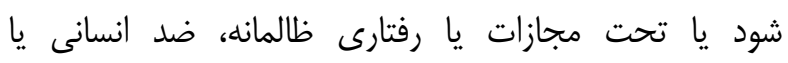

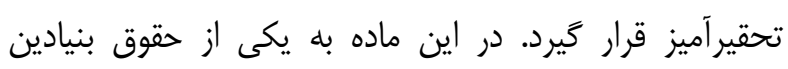

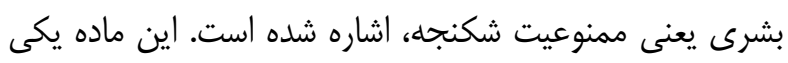

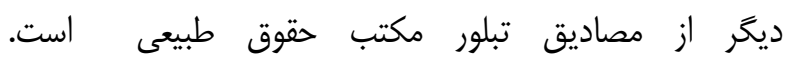
(Celermajer, 2018: 32) حق بر شخصيت افراد انسانى مورد توجه ماده ششم اعلاميه

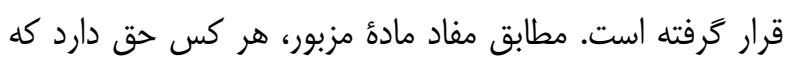

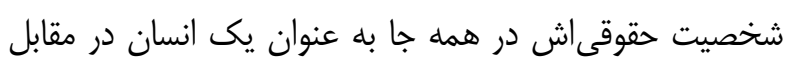

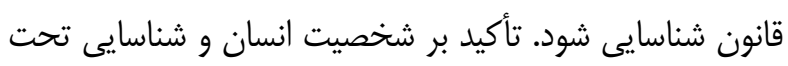

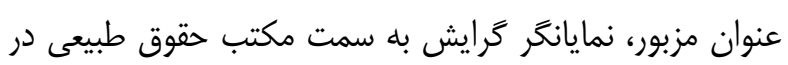

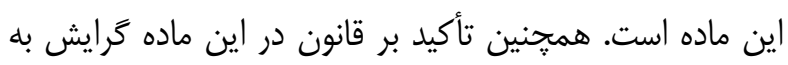
Kippenberg ( سمت مكتب اصالت قاعده را نيز نشان مى مهند

(et al, 2012: 26

r-ו-ץ- اصول مربوط به دادگسترى: اصل برابرى در ماده هفتم از اعلاميه مورد تصريح قرار كرفته است. مطابق با مادهٔ

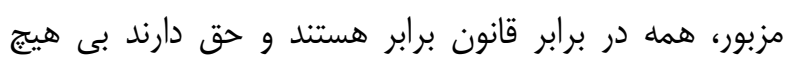
تبعيضى از حمايت يكسان قانون برخوردار شوند. همه حق دارند

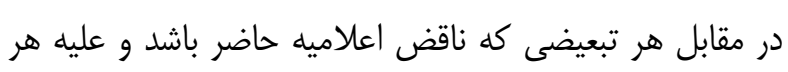
تحريكى كه براى جنين تبعيضى به عمل آيد به طور مساوى از

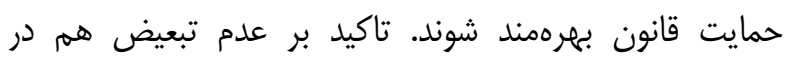
برخوردارى از امتيازات قانون و هم در برخوردارى از حمايت 
وجود دارد. ب) مكتب دوكانكى يا دوئليسه، كه مطابق ديدكاههاى طرفداران اين مكتب بين حقوق بين المللى و حقوق دورد

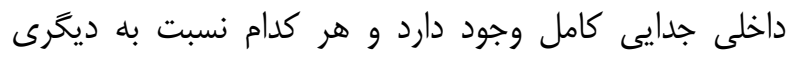
مستقل است. در ظاهر اين ماده به نظر مىرسد گرايش بـ به سمت برابرى نظام حقوقى بينالملى با نظام حقوقى داخلى

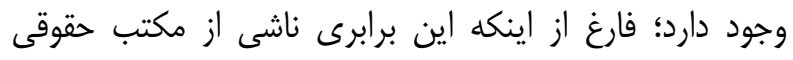

مونوئيسم يا دوئاليسم مى باشد. (Nolan, 2015: 215)

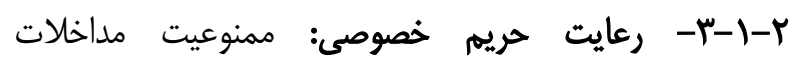

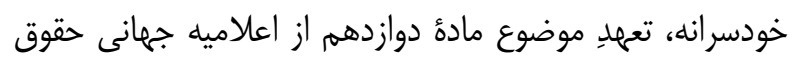
بشر مىباشد. به موجب مفاد ماده مزبور، نبايد در زندگى

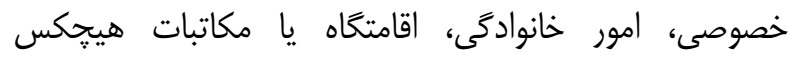

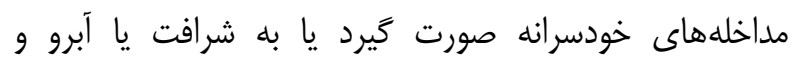
شهرت كسى حمله شود. در برابر هنين مداخلهها و حملههايى، برخوردارى از حمايت قانون، حق هر شخص است. در اين ماده، حقوق فرد در مناسباتش با گروههاى اجتماعى و بيرونى مد نظر حرى قرار گرفته شده است كه اين مسأله نشان از گرايش به به سمت مكتب اصالت اجتماع دارد. همجنين تاكيد بر حمايت قانون و و

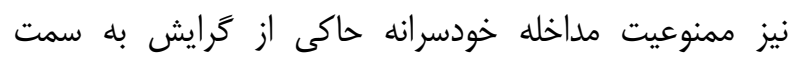

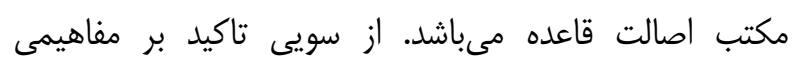
همجون شرافت، آبرو و شهرت، كرايش به سمت مكتب حقوق

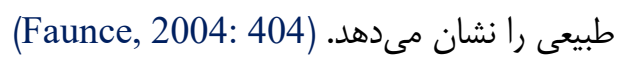
r-1-ז- حق بر آزادى تردد: كه موضوع ماده سيزدهم از اعلاميه است. به موجب مفاد مادة مزبور، هر شخص حق دارد در داخل هر دولت آزادانه تردد كند و اقامتگاه خود را بركزيند. r) هرشخص حق دارد هر دولتى، از جمله متبوع خود را ترى درى

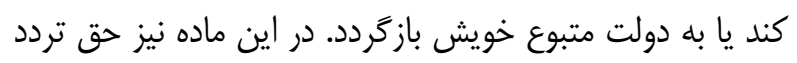

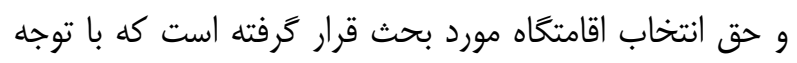

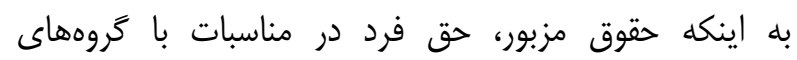
اجتماعى مىباشد، مىتوان گرايش به سمت مكتب اصالت

اجتماع رادر آن مشاهده كرد. (Adimassu, 2015: 48)

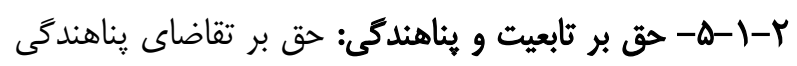
در ماده جهاردهم مورد توجه قرار گرفته است. مطابق مفاد ماده

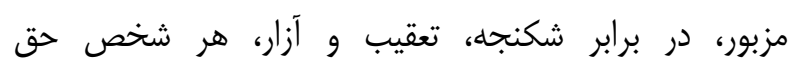

حقوق طبيعى است. از طرفى ديخر تاكيد بر محكمه بىطرف و

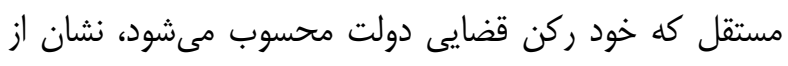

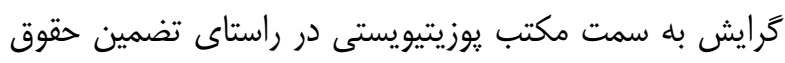

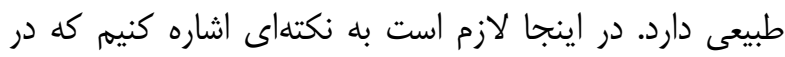

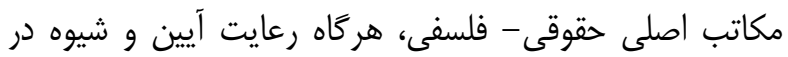

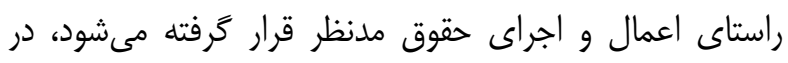
واقع مكتب مورد نظر داراى گرايشى فرماليستى است. به بيان

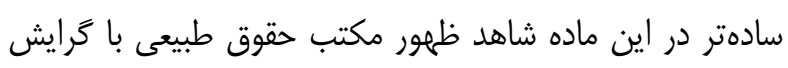

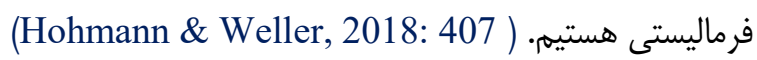
اصل برائت و اصل عطف به ماسبق نشدن قوانين كيفرى نيز در

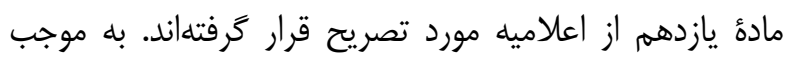

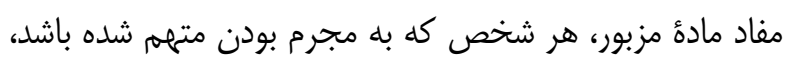

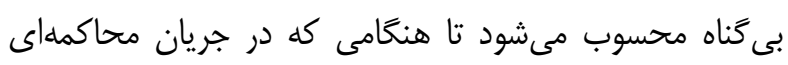

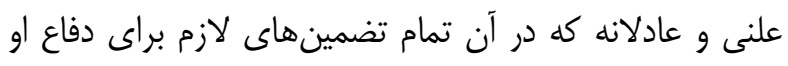

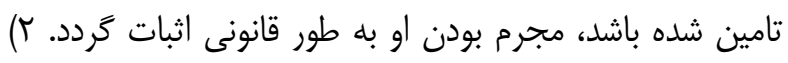

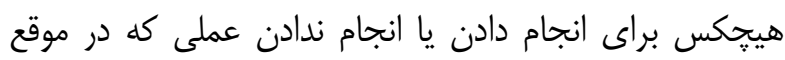
ارتكاب به آن به موجب قوانين ملى يا بينالمللى جرم نبوده

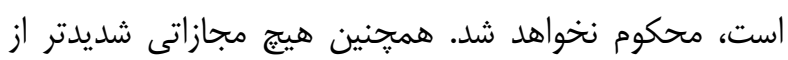
مجازاتى كه در موقع ارتكاب جرم به آن تعلق مى گرفت، درباره

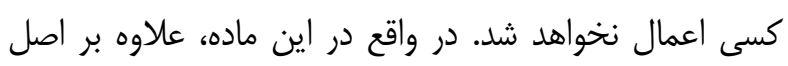

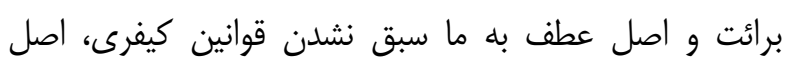
قانونى بودن جرائم و مجازاتها نيز مورد اشاره قرار كَرفته است. اين اصول جزء اصول مكتب حقوق طبيعى مىباشند. همجنين

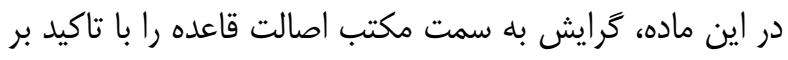
اصل قانونى بودن جرائم و مجازاتها مىتوان مشاهده نمود. اما

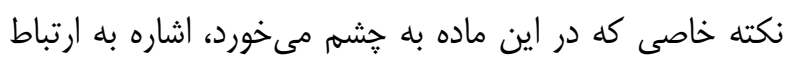
نظام حقوق داخلى و حقوق بينالمللى است. در ديدكاههاى

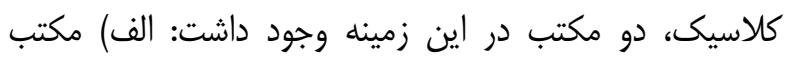
مونوئيسم، كه مطابق ديدكاههاى طرفداران اين مكتب نظام حقوقى داخلى و نظام حقوقى بينالملى از يكديكر جدا نبوده، بلكه قسمتهاى مختلفى از يك بناى واحد حقوقى را تشكيل

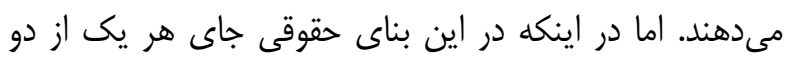
رشته حقوق كجا بايد باشد، بين ييروان اين مكتب اختلاف نظر 
انحلال آن زن و شوهر در امور مربوط به ازدواج حقوق برابر

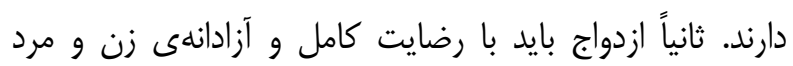

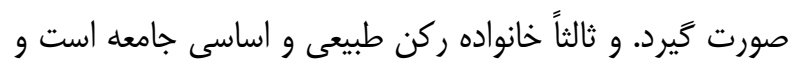
بايد از حمايت جامعله و دولت بهرهمند شود. مفاهيمى همجيون

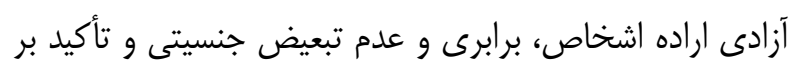

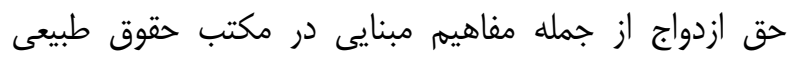

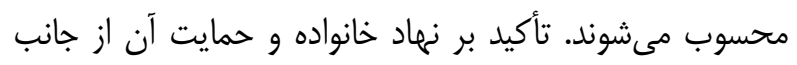

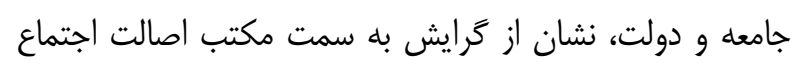
دارد. تأكيد بر برابرى در معناى مساواتِ مطلق با ديدكاه مكاتب فلسفى اسلامى در ظاهر امر همخوانى ندارد و به همين دليل است كه كشورهاى اسلامى نسبت به اعلاميه جهانى حقوق بشرى در ابتدا موضع گيرىهاى انتقادى داشتند كه اين مواضع يس از جلسات و مباحثات مختلف به نحوى تعديل شد كه از

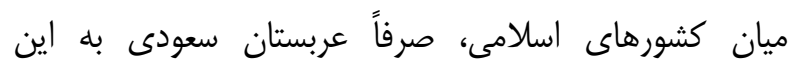
اعلاميه راى ممتنع داد. در اينجا بحث در مورد هُّونكى تعديل مواضع دولتهاى اسلامى خارج از حوصله مختصر حاصل

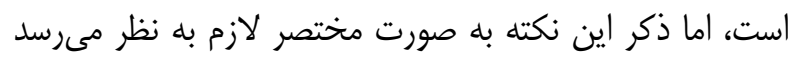

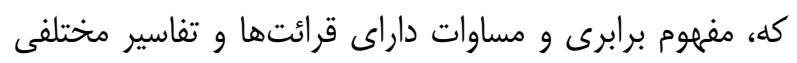

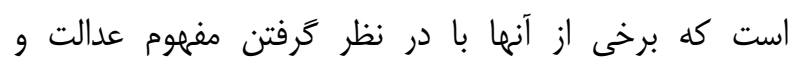
مناسبات آن با مفهوم مساوات در مكاتب فلسفى اسلامى قابل هضم مىباشد. (Loveless \& Holman, 2007: 192) Y-I-Y حق مالكيت: كه در ماده IV اعلاميه مورد اشاره قرار كرفته است. مطابق ماده مزبور، اولاً هر شخص به ماله تنهايى يا به صورت جمعى حق مالكيت دارد و ثانياً هيجكس رانس را نبايد خودسرانه از حق مالكيت محروم كرد. نفس حق حق مالكيت دات الكيت از جمله حقوق قائم بر شخصيت انسانى است. مبانى اين حق در مارد مكتب فلسفى حقوق طبيعى تعريف مىشود. اما در ارتباط با

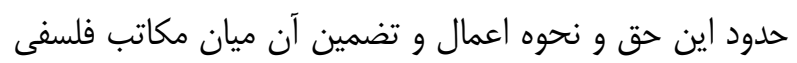
سياسي مختلف، از جمله مكاتب سوسياليستى، كمونيستى، كييتاليستى و غيره، اختالافتى وجود دارد. ( Heijden \&

(Tahzib-Lie, 1998: 122
درخواست پِناهندگى و برخوردارى از يناهندگى در دولتهاى

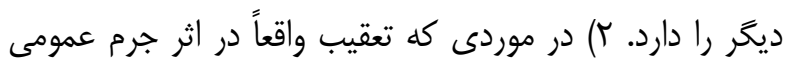
و غير سياسى باشد، نمىتوان به اين حق استناد كرد. در اين

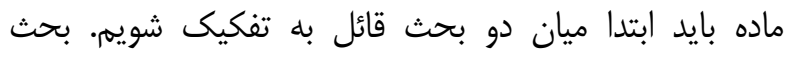

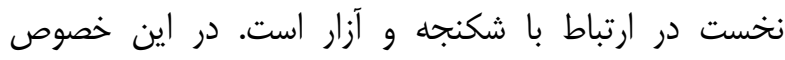

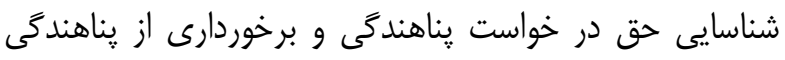
در ارتباط با شكنجه به صورت مطلق بيان شده كه حاكى از

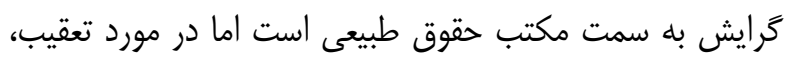

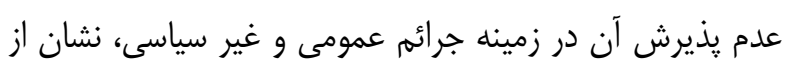

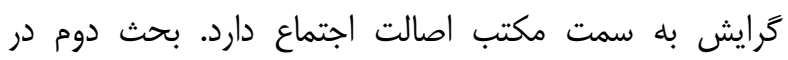
ارتباط با امكان اعطاء هناهندگى از جانب دولت ثالث است كه

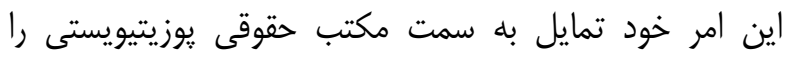

نشان مىدهد. (Da Lomba, 2004: 162) حق بر داشتن تابعيت نيز در مادهٔ يانزدهم از اعلاميه مورد توجه

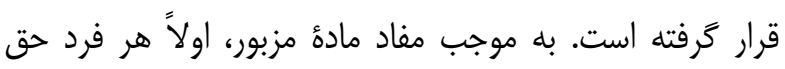

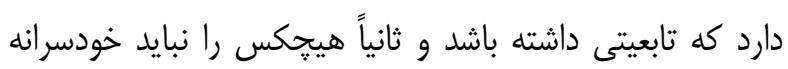
از تابعيت خويش، يا از حق تغيير تابيعيت محروم كرد. اساساً

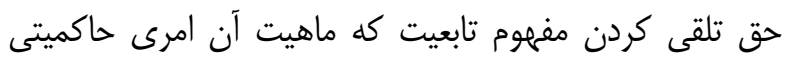

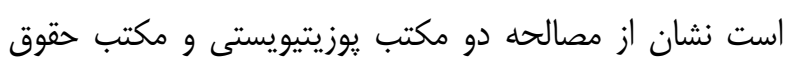

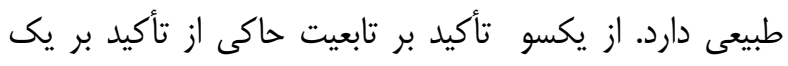
نظام حقوقى دولت محور است كه اين دولت محورى خود نماد كرايش بله سمت مكتب يوزيتيوستى است. از سوى ديخر تأكيد

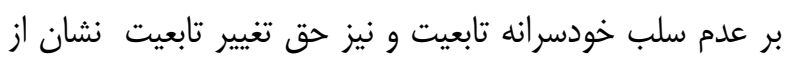

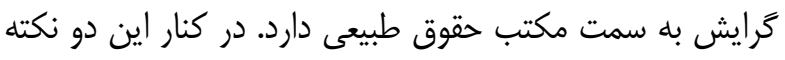
مسأله ديخرى كه حائز اهميت است اين است كه اساساً مفهوم

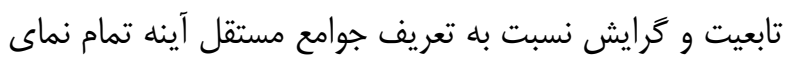
مكتب اصالت اجتماع مى باشد. (Guðmundur, 1999: 299) r-ו-צ- حق بر ازدواج و تشكيل خانواده: اين حق نيز مورد

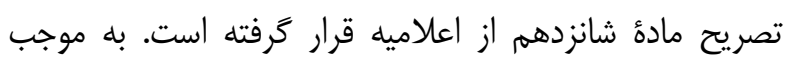

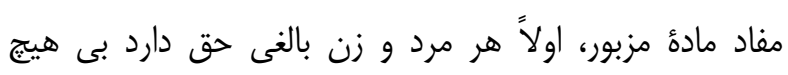

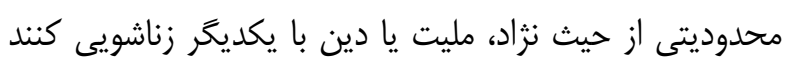
و تشكيل خانواده بدهند. در تمام مدت زناشويى و هنگًام 
مىرسد در اينجا گرايش به مكتب قرارداد اجتماعى (به جاى

اصالت اجتماع)، مشاهده مىشود. (Sharma, 2010: 25) حق بر مشاركت اشخاص در امور سياسى و عمومى كشور نيز در ماده بيست و يكم اعلاميه مورد توجه و تأكيد قرار ترفته

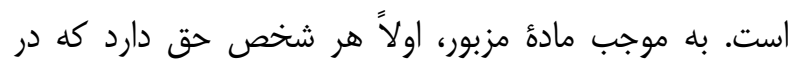

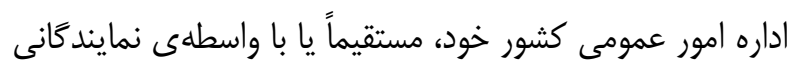
كه آزادانه انتخاب شده باشند، مشاركت كند. ثانياً هر شخص آنص

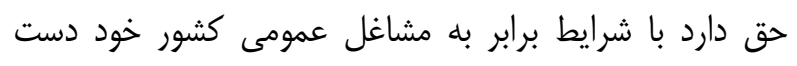

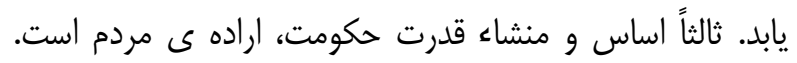
اين اراده بايد در انتخاباتى سالم ابراز شود كه بلطور ادوارى

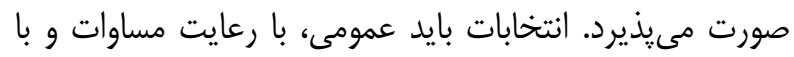

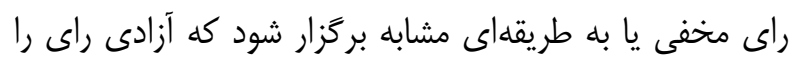
تامين كند. در اين ماده حق تعيين سرنوشت و اعمال آن از از طريق امكان دستيابى مشاغل عمومى با شرايط برابر و بركزارى

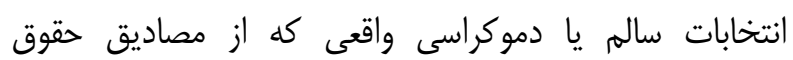
سياسى مىباشند، مورد اشاره قرار گرفته است. به نظر مىرسد اين ماده گرايش بله مكتب حقوق طبيعى نوين دارد. (Modrzejewski, 2012: 35)

ץ-1-9- حق بر امنيت اجتماعى: كه در ماده بيست و دوم از

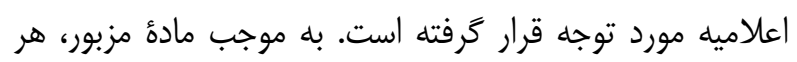
شخص به عنوان عضو جامعه حق امنيت اجتماعى دارد و مجاز است تا به يارى مساعدت ملى و همكارى بينالمللى، حقوق اقتصادى، اجتماعى و فرهنكى ضرورى براى حفظ حيثيت و كرامت و رشد آزادانه شخصيت خود را، با رعايت تشكيلات و و وركائ

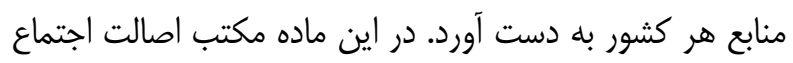
با تأكيد بر حق امنيت اجتماعى خودنمايى مى كند. حقوق اقتصادى، اجتماعى و فرهنگى به عنوان حقوقى فطرى در قالب اجني مكتب حقوق طبيعى نوين تعريف مىشود. تاكيد بر مساعدت

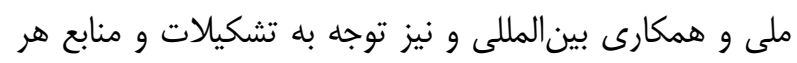
دولت نشان از مكتب وين يا همان مكتب حقوق وضعى دارد. زيرا در قابل اين مكتب است كه صرفاً دولت تجلى يكى نظان منام حقوقى مى باشد. بايد توجه داشت كه گرايش به اين مكاتب در

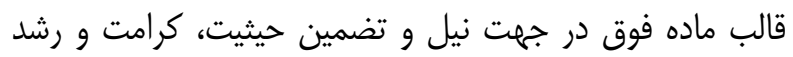

ץ-1-1- اصول مربوط به آزادى: اصل آزادى موضوع ماده

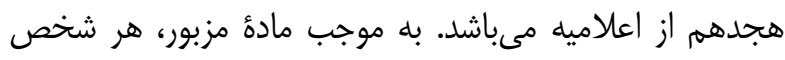

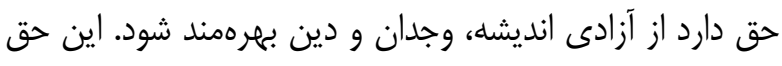

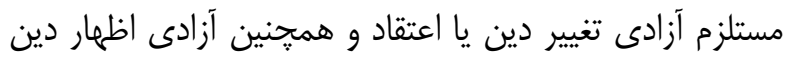

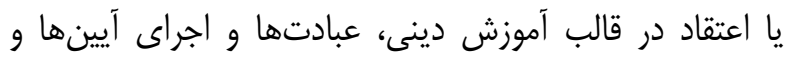
مراسم دينى به تنهايى يا به صورت جمعى بلهور خصوصى يا

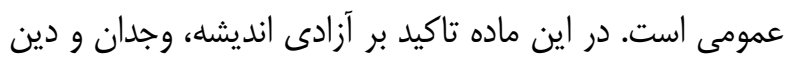
هم در بعد فردى و هم در بعد اجتماعى مد نظر قرار كرفته است. ير واضح است كه كرايش به مكاتب اصالت اجتماع و

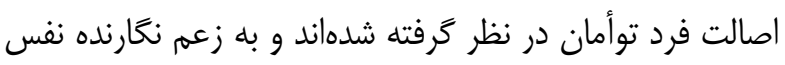
اين حقوق ريشه در مكتب حقوق طبيعى دارد، حال آنكه نفس اين حقوق به عقيده اغلب نويسندكان ريشه در مكتب حقوق طبيعى نوين دارد. در اينجا در ارتباط با حدود و نحوه اجراى لهون

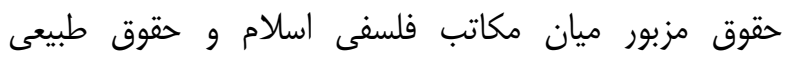
اختلاف نظر وجود دارد. (Sharma, 2011:86) اصل آزادى عقيده و بيان نيز مورد توجه ماده نوزدهم اعلاميه

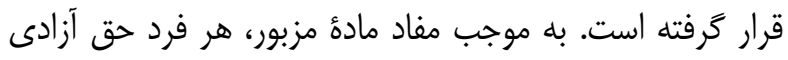

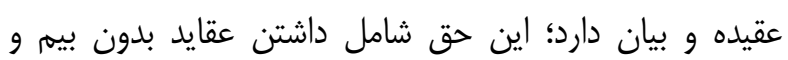

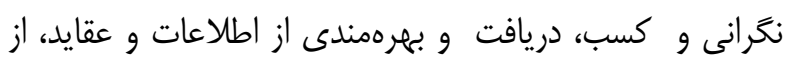
طريق هر رسانهاى فارغ از محدوديتهاى مرزى مى شود. در اين ماده يكى از مصاديق خاص آزادى يعنى آزادى عقيده و

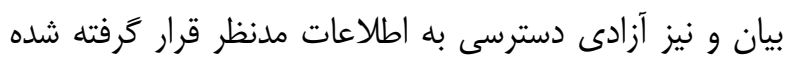
است. اين حقوق جزء حقوق طبيعى انسانها اما نه در قالب مكتب حقوق طبيعى بلكه در قالب مكتب حقوق طبيعى نوين مىباشد. (Weissbrodt \& Vega, 2007: 102) اصل آزادى تشكيل اجتماعات در مادهٔ بيسته اعلاميه مورد

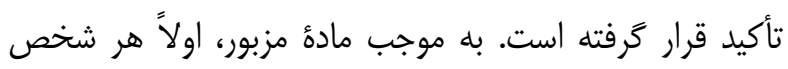

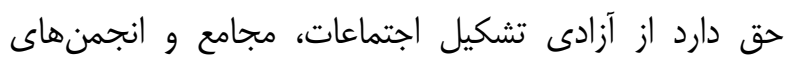

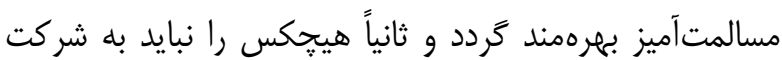
در هيج اجتماعى مجبور كرد. در اين ماده حق فردى نسبت به

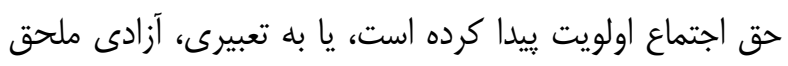

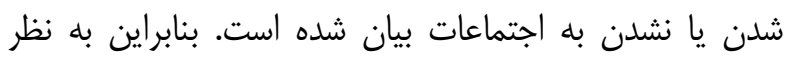


ماده بيست و ينجم از اعلاميه به حق بر رفاه يرداخته است. به

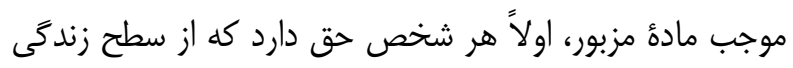

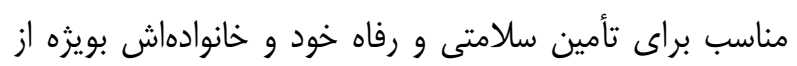
حيث خوراك، يوشاك، مسكن، مراقبتهاى يزشكى و خدمات ندات

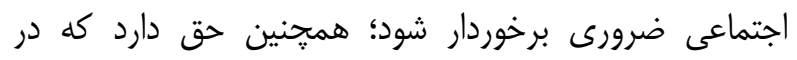
مواقع بى كارى، بيمارى، نقص عضو، بيوگى، ييرى يا در تمام

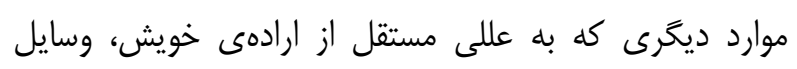
امرار معاشش را از دست داده باشد، از تأمين اجتماعى بهرهمند

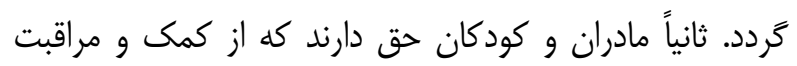
ويزه برخوردار شوند. همه كودكان خه بر اثر ازدواج و خه بدون ازدواج به دنيا آمده باشند، به طور يكسان، حق دارند كه از حمايت اجتماعى يكسان بهرهمند گردند. بند اول اين ماده با با باديا

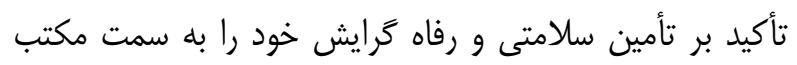

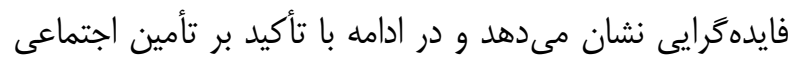
در قالب مكتب قرارداد اجتماعى گام بر مىدارد. در غالب مكتب دمان حقوق طبيعى نوين مىتوان جنين استدلال نمود كه مطابق عقل سليم (صد البته مقصود از عقد سليم در اينجا، حكم فطرت است)، عدالت ايجاب مى كند كه مادران و كودكان بواسطه

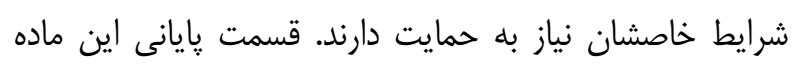

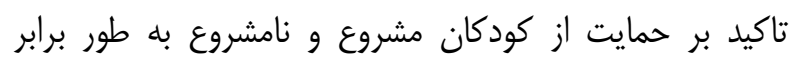

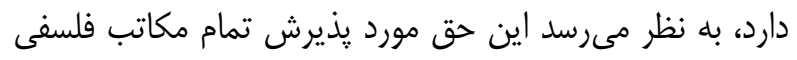
از جمله، مكتب فلسفى اسلامى، قرار دارد. ( Guðmundur,

r-ו-1|- حق بر آموزش و يرورش: اين حق نيز در مادة

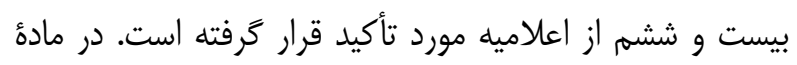
مزبور، اولاً هرشخص حق دارد كه از آموزش و يرورش بهرهمند فئد شود. آموزش و يرورش و حداقل، آموزش ابتدايى و يايه بايد

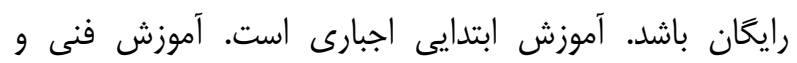
حرفهاى بايد همخانى شود و دستيابى به آموزش عالى بايد با باسيا

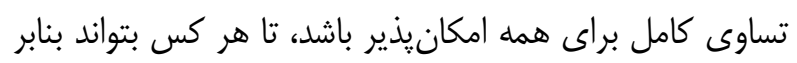

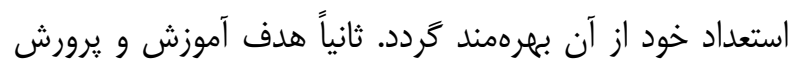
بايد شكوفايى همهجانبه شخصيت انسان و تقويت رعايت حقوق
آزادانهى فرد انسانى مىباشد كه اين امر خود تبلور مكتب حقوق طبيعى را مىرساند. (Riedel, 2006: 23)

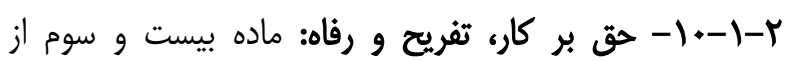
اعلاميه به حق بر كار يرداخته است. به موجب مادهُ مزبور، اولاًا

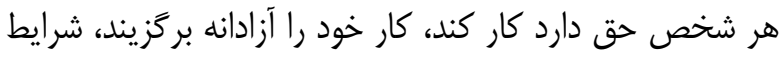
منصفانه و رضايتبخشى براى كار خواستار باشد و در برابر

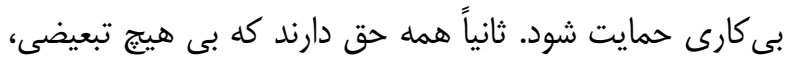

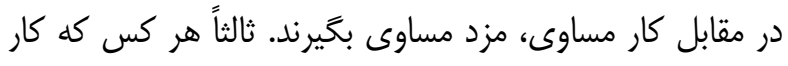

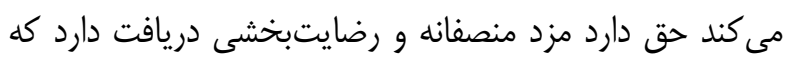

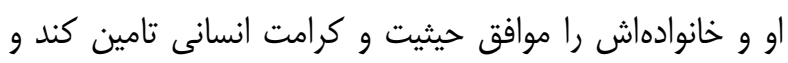
در صورت لزوم با ديخر تدابير و وسايل حمايت اجتماعى كامل حيل

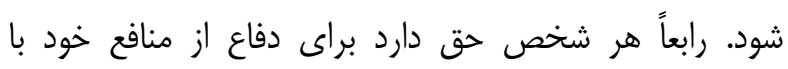
ديخران اتحاديه تشكيل دهد و يا به اتحاديههاى موجود بييوندد.

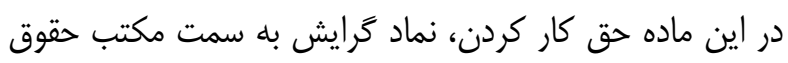

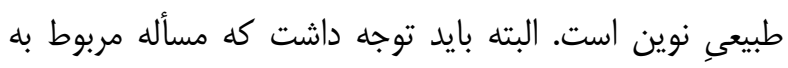
كار مساوى و مزد مساوى در ابتدا يك بحث هالشى ميان

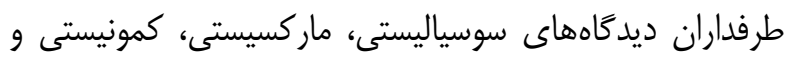
ساير جريانهاى سياسى بود. بدون ترديد اين حق در راستاى

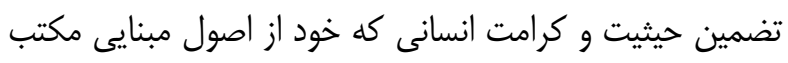

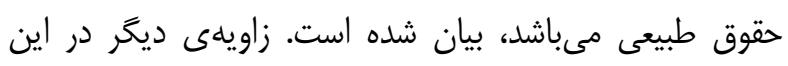

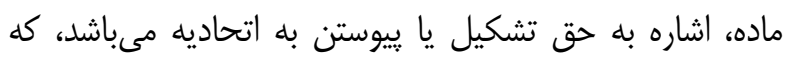

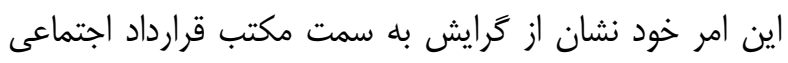

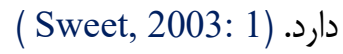
حق بر استراحت و فراغت در ماده بيست و جههارم اعلاميه مورد

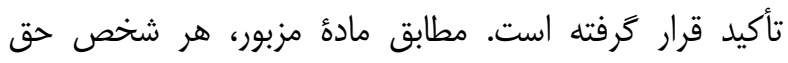

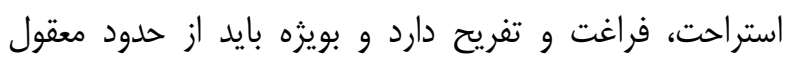

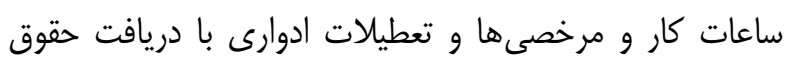
بهرهمند شود. اين ماده در راستاى افزايش سطح خوشبختى ماتى تعريف شده است. به نظر مىرسد در اعلاميه جهانى حقوق بشر مارد

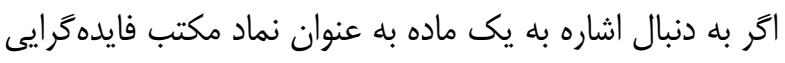

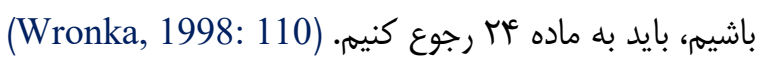


موجب مفاد ماده مزبور، اولاً هر كس در مقابل آن جامعهاى وظيفه دارد كه رشد آزادى و كامل شخصيت او را ميسر سازد. ثانياً هر كس در اجراى حقوق و استفاده از آزادىهاى خود، فقط تابع محدوديتهايى است كه بوسيله قانون، منحصراً به منظور تأمين شناسايى و مراعات حقوق و آزادىهاى ديخران و براى رعايت مقتضيات عادلانهى اخلاقى و نظم عمومى و رفاه همخانى، در شرايط يك جامعه دموكراتيك وضع گرديده است.

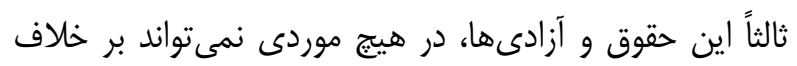
مقاصد و اصول ملل متحد اجرا گردد. بند يك اين ماده با تفوق اصالت فرد بر اصالت جامعه، از مكتب فسلفى اصالت اجتماع فاصله گرفته است و به سمت مكتب فلسفى اصالت فرد گرايش دارد. در بند دو، محوريت قانون، نشان از زرايش به سمت مكتب اصالت قاعده و نيز تمايل به سمت رفاه و نظم عمومى حاكى از تمايل به سمت فايده گرايى دارد. بند سه با عبارتى كوتاه اما معنادار، اصول و مقاصد ملل متحد را به عنوان خط قرمز اعلاميه جهانى حقوق بشر تعريف مى كند. به تعبيرى با آمدن اين بند، كليهى گرايشها و مكاتب مورد بحث در اين اعلاميه، صرفاً تا حدى مورد يذيرش واقع مىشوند كه با مقاصد و اصول منشور ملل متحد كه اساساً بر مبناى مكتب يوزيتيويستى تعريف شده است، در تعارض نباشند. صد البته نغارنده به اين امر واقف است كه مقاصد و اصول ملل متحد، صرفاً بر مبناى مكتب يوزيتيويستى تنظيه و تعريف نشده است، بلكه مكتب حقوق طبيعى نيز تا حدودى در اين وادى حضور دارد، اما به هر حال، اين مكتب يوزيتيويستى است كه در تعريف مقاصد و اصول ملل متحد نقش اصلى را ايفا مى كند.

(Takemura, 2008: 211) ايجاد محدوديت براى حقوق مندرج در اعلاميه، در ماده يايانى يعنى ماده سىام مورد توجه قرار گرفته است. به موجب مفاد اين ماده، هيج يك از مقررات اعلاميه حاضر نبايد به نحوى تفسير شود كه متضمن حقى براى دولتى يا جمعيتى يا فردى باشد كه به موجب آن بتواند هريك از حقوق و آزادىهاى مندرج در اين اعلاميه را از بين ببرد و يا در آن راه فعاليتى بنمايد. نحوهى بيان اين ماده، حاكى از اين امر است كه حقوق
بشرى و آزادىهاى اساسى باشد. آموزش و يرورش بايد به كسترش حسن تفاهم، دكريذيرى و دوستى ميان تمام ملتها و تمام گروههاى نزادى يا دينى و نيز به گسترش فعاليتهاى ملل متحد در راه حفظ صلح يارى رساند. ثالثاً والدين در انتخاب نوع آموزش و يرورش براى فرزندان خود بر ديگران حق تقدم دارند. در اين ماده حق بر آموزش و يرورش به عنوان يكى از حقوق مبنايى در جهت ارتقاء ساير حقوق و آزادىهاى اساسى بشرى تعريف شده است. به تعبيرى مكتب فايدهرايى در راستاى تضمين حقوق موضوع مكتب حقوق طبيعى مورد اشاره قرار گرفته است. همجنين در اين ماده اشارهاى به نظام ملل متحد كه محور اصلى آن مكتب يوزيتيويستى مىباشد، شده

است. (De Beco et al, 2019: 346)

r-ו-Iו- حق بر زندكى فرهنكى: مادهٔ بيست و هفتم از اعلاميه به حق بر زندگى فرهنگَى زرداخته است. مطابق مفاد

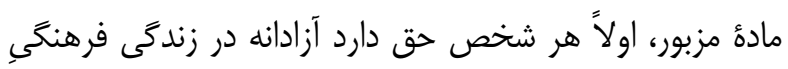
اجتماع، سهيم و شريك گردد و از هنرها و بويزه از ييشرفت

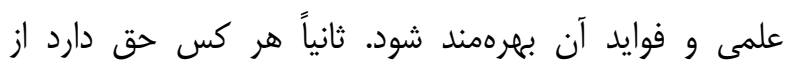
حمايت منافع معنوى و مادى آثار علمى، ادبى يا هنرى خود برخوردار گردد. بند اول اين ماده با اولى تلقى كردن حقوق فردى، گرايش به سمت مكتب قرارداد اجتماعى دارد. در بند دوم نيز نفس مالكيت فكرى، نشان از زرايش به سمت مكتب حقوق طبيعى دارد. (Donders, 2007: 242) r-ו-ץו- حق مطالبة نظم حقوقى: مادهٔ بيست و هشتم اعلاميه به اين حق يرداخته است. مطابق مفاد ماده مزبور، هر كس حق دارد برقرارى نظمى را بخواهد كه از لحاظ اجتماعى و بينالمللى حقوق و آزادىهايى را كه در اين اعلاميه ذكر گرديده است تأمين كند و آنها را مورد عمل بحذارد. حق مطالبه نظهم حقوقى، نماد اصلى كرايش به سمت مكتب اصالت قاعده مىباشد. اين ماده آيينه تمام قد گرايش به سمت مكتب اصالت Keane \& McDermott, 2012: ) اراده محسوب مىشود.

r-r-r وظايف و محدوديتها: وظيفه افراد در برابر جامعه نيز مورد توجه ماده بيست و نهم اعلاميه قرار گرفته است. به 
محاسبات، قلمداد شده است. در مورد اينكه اولين نظم تنظيمكننده روابط קه نظمى و با خه وضعيتى بوده است، ميان

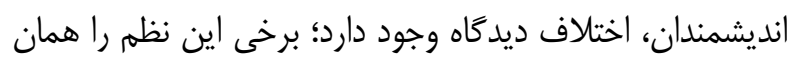
نظه حاكم بر يونان باستان دانستهاند و برخى ديخر، نظم مزبور را نظم ايران باستان در نظر گرفتهاند. به هر روى با كذشت زمان تحولات زيادى در نظه حاكم بر روابط اشخاص ايجاد

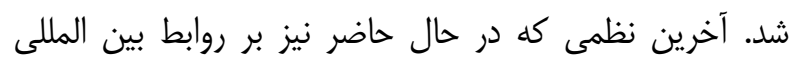
حاكم است، نظم منشور ملل متحد است؛ نظمى كه مهمترين جالش آن، علىرغه ادعاى بسيارى از نويسندًان و انديشمندان

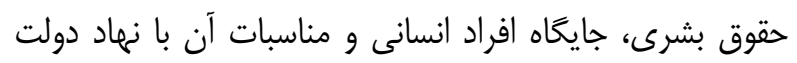

شايد وقت آن رسيده است كه حقوقدانان، بازطراحى نظم حقوق بينالمللى را مورد توجه ويزه قرار دهند. نظمى كه در آن محور اصلى، بازيخران آن نمىباشند، بلكه حقوق بينالمللى در كليت

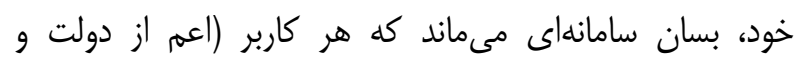
غيردولت) حسب ويزَى ها و ابزارهاى خود مى حتواند از آن بهرها

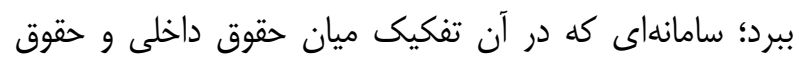

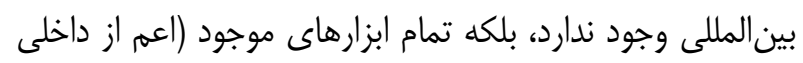

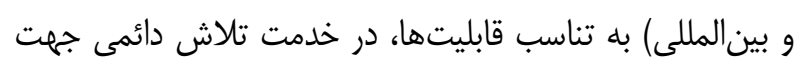
دستيابى به يك هدف واحد، كه همان افق صلح جاويدان

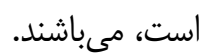
ملاحظات اخلاقى: موارد مربوط به اخلاق در يزوهش و نيز

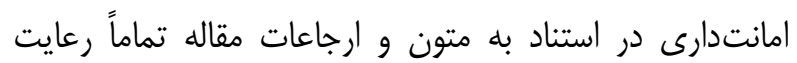
كرديد. تعارض منافع: تدوين اين مقاله، فاقد هرَّنه تعارض منافعى بوده است. سهم نويسندكان: نغارش متن توسط نويسندكان و نظارت علمى و اصلاحات نهايى توسط نويسنده مسؤول صورت كرفت. تشكر و قدردانى: از تمامى كسانى كه در تهيه اين مقاله ما را يارى رساندند، تشكر مىنماييه.

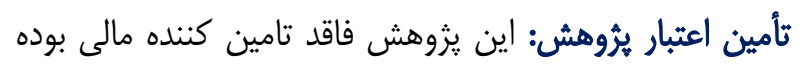

مندرج در اين اعلاميه، ناشى از شخصيت انسانى و قائم به آن

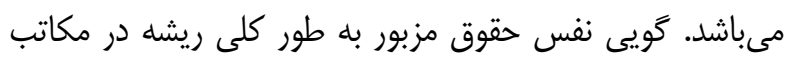

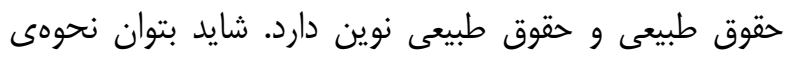
بيان صدر اين ماده را هنين تلقى كرد كه قصد تدوين كنندكان اعلاميه بستن راه دولتها براى ايجاد رويهى مخالف حقوق

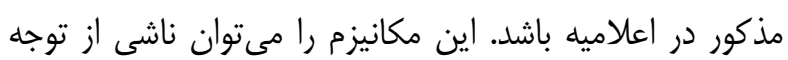
به مكتب رئاليسم سياسى تلقى نمود.

\section{نتيجه}

هم در جيدمان اعضاء كميسيون تدوين متن اعلاميهى جهانى حقوق بشرى و هم در متن مواد تصويب شده از سوى دولتها

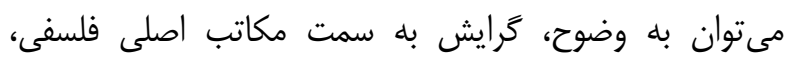
حقوقى و سياسى را مشاهده كرد. در واقع در اين اعلاميه مىتوانيم شاهد مصالحه اين مكاتب و ديدكاهها با يكديخر

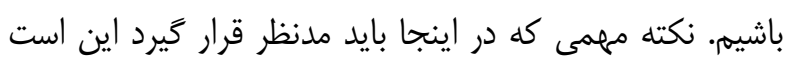

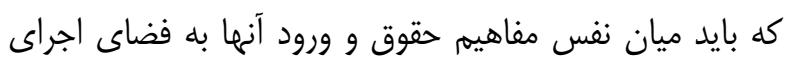
حقوق بين المللى قائل به تفكيك شويه. به بيان سادهتر هر نهاد

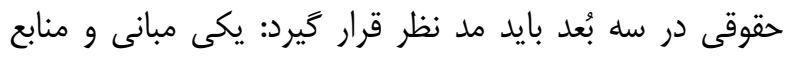

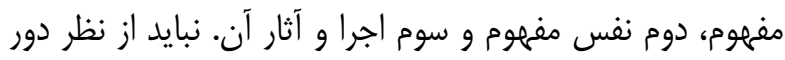
داشت كه هر مفهوم با اين سه مرحله در يك نظمه قرار

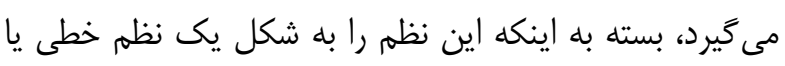

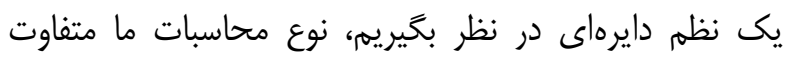

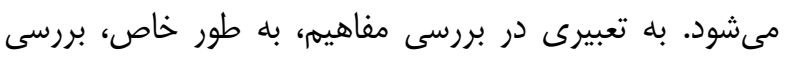

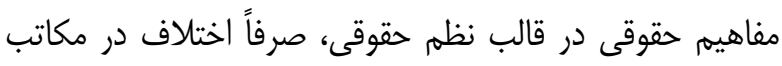
فلسفى، حقوقى و سياسى، موجب اختلاف در ديدكاهها و احكام

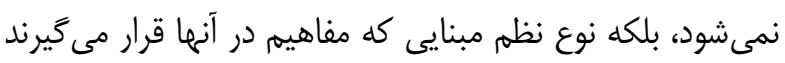

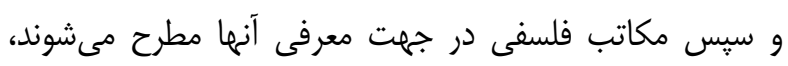
اساس تفاوت در ديدكاهها و احكام مىباشد.

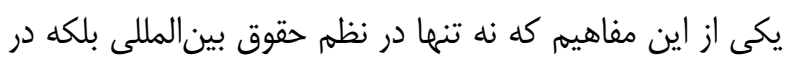
ساير حوزهها از جمله اخلاق، سياست و غيره مطرح مى لهود مفهوم حقوق بشر است. ترديدى نيست كه عالم حقوق عالم تنظيم روابط افراد انسانى است. بنابراين، حقوق بشرى از زمان

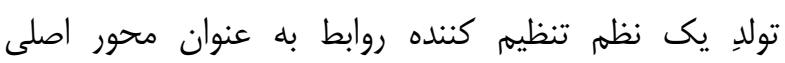


- Donders, Y \& Volodin, V (2007). Human Rights in Education, Science, and Culture. UNESCO.

- Eckes, C (2009). EU Counter-Terrorist Policies and Fundamental Rights: The Case of Individual Sanctions. Oxford: Oxford University Press.

- Faunce, T (2004). Pilgrims in Medicine: Conscience, Legalism and Human Rights: An Allegory of Medical Humanities, Foundational Virtues, Ethical Principles, Law and Human Rights in Medical Personal and Professional Development. London: Brill.

- Goodman, R \& Jinks, D (2004). "How to Influence States: Socialization and International Human Rights Law". Duke Law Journal, 54 (3): 621-703.

- Hakonssen, K (1996). Natural Law and Moral Philosophy: From Grotius to the Scottish Enlightenment. Cambridge: University Press.

- Heijden, B \& Tahzib-Lie, B (1998). Reflections on the Universal Declaration of Human Rights: A Fiftieth Anniversary Anthology. Hague: Martinus Nijhoff Publishers.

- Hochstrasser, T (2000). Natural Law theories in the Early Enlightenment. Cambridge: University Press.

- Hohmann, J \& Weller, M (2018). The UN Declaration on the Rights of Indigenous Peoples: A Commentary. Oxford: University Press.

- Hugo, G (2002). The Rights of war and Peace. Vol 1, Hague: Liberty Fund.

- Keane, D \& McDermott, Y (2012). The Challenge of Human Rights: Past, Present and Future. London: Edward Elgar.

- Kippenberg, H; Kuiper, Y \& Sanders, A (2012). Concepts of Person in Religion and Thought. Berlin: Mouton de Gruyter.

$$
\begin{aligned}
& \text { منابع و مآخذ } \\
& \text { الف. منابع فارسى و ماسى } \\
& \text { - باقرى، محمود (1) (1). مكاتب فلسفى در حقوق بينالملل. }
\end{aligned}
$$

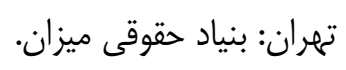

$$
\begin{aligned}
& \text { - ذوالعين، يرويز (•وسا). مبانى حقوق بين الملل عمومى، } \\
& \text { جاب هفتم، تهران: دفتر مطالعات سياسى و بينالملى. رئ. } \\
& \text { - عاليخانى، محمد (•ربا). حقوق بين/الملل. تهران: انتشارات } \\
& \text { خط سوم. } \\
& \text { - عاليخانى، محمد (بوسו). هويت ملى /يرانيان. تهران: }
\end{aligned}
$$

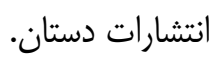

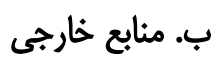

- Adimassu, Y (2015). The Right to Freedom of Movement and Residence. Hamburg: Anchor Academic Publishing.

- Aure, A (2008). Secular and Subjective Concept of Natural Law. Grmany: Max Planck Institute for European Legal History.

- Bahalla, L (1991). Human Right an Institutional Framework for Implementation. Delhi: Docta Shelf.

- Brett, A (1997). Liberty, Right and Nature: Individual Rights in Later Scholastic Thought. Cambridge: University Press.

- Celermajer, D (2018). The Prevention of Torture: An Ecological Approach. Cambridge: Cambridge University Press.

- Da Lomba, S (2004). The Right to Seek Refugee Status in the European Union. Oxford: Intersentia.

- De Beco, G; Quinlivan, S \& Lord, J (2019). The Right to Inclusive Education in International Human Rights Law. Cambridge: Cambridge University Press. 
Cambridge: University Press.

- Riedel, E (2006). Social Security as a Human Right. London: Springer.

- Sharma, A (2010). Universal Declaration of Human Rights and Indian Law. New Delhi: PHI Learning.

- Sharma, A (2011). Problematizing Religious Freedom. London: Springer.

- Spaak, T (2014). A Critical Appraisal of Karl Olivecrona's Legal Philosophy. Switzerland: Springer.

- Sweet, W (2003). Philosophical Theory and the Universal Declaration of Human Rights. Ottawa: University of Ottawa Press.

- Takemura, H (2008). International Human Right to Conscientious Objection to Military Service and Individual Duties to Disobey Manifestly Illegal Orders. London: Springer.

- Tierney, B (1997). The Idea of Natural Rights: Studies on Natural Rights, Natural Law and Church Law, 1150-1625. Atlanta: Scholars Press.

- Tomuschat, C (2003). Human Rights: Between Idealism and Realism. Oxford: Oxford University Press.

- Weissbrodt, D \&, Vega, C (2007). International Human Rights Law: An Introduction. Pennsylvania: University of Pennsylvania Press.

- Wodon, Q (2001). Attacking Extreme Poverty: Learning from the Experience of the International Movement ATD Fourth World. Vol 23, Washington: World Bank Technical Paper.

- Wronka, J (1998). Human Rights and Social Policy in the $21^{\text {st }}$ Century. US: University Press of America.
- Lawson, E \& Lou Bertucci, M (1996). Encyclopedia of Human Rights. London: Taylor \& Francis.

- Loveless, S \& Holman, T (2007). The Family in the New Millennium: The Place of Family in Human Society. London: Praeger.

- Mansbach, R (2012). Introduction to Global Politics. $2^{\text {nd }}$ ed. London and New York: Routledge Taylor and Francis Group.

- Marias, J (1967). History of Philosophy. New York: Dover Publications.

- McCrudden, C (2015). Human Rights: Law, Politics, And Philosophy. Michigan: University of Michigan Law School.

- Menendez, A (2006). Arguing Fundamental Right. Netherland: Springer.

- Miguelángel, V; Philani, M \& Wilkins, A (2020). The Global Politics of Human Rights: Bringing the Universal Declaration of Human Rights. New York: UNISA.

- Modrzejewski, B (2012). Law Books. Bialystok: Wydawnictwo Temida.

- Morsink, J (1996). The Universal Declaration of Human Rights: Origins, Drafting, and Intent. Pennsylvania: University of Pennsylvania Press.

- Nolan, C (2015). Ethics and Statecraft: The Moral Dimension of International Affairs. Denver: ABC-CLIO.

- Oakley, F (2005). Natural Law, Laws of Nature, Natural Rights: Continuity and Discontinuity in the History of Ideas. New York - London: Continuum.

- Reidar, M \& Schaffer, J (2017). Moral and Political Conceptions of Human Rights: Implications for Theory and Practice. 


\section{References}

- Adimassu, Y (2015). The Right to Freedom of Movement and Residence. Hamburg: Anchor Academic Publishing.

- AliKhani, M (2001). International Law. Tehran: Khat Sevom Publishing. (Persian)

- AliKhani, M (2001). Iranians National Identity. Tehran: Dastan Press. (Persian)

- Aure, A (2008). Secular and Subjective Concept of Natural Law. Grmany: Max Planck Institute for European Legal History.

- Bagheri, M (2009). Philosophical Schools in International Law. Tehran: Mizan. (Persian)

- Bahalla, L (1991). Human Right an Institutional Framework for Implementation. Delhi: Docta Shelf.

- Brett, A (1997). Liberty, Right and Nature: Individual Rights in Later Scholastic Thought. Cambridge: University Press.

- Celermajer, D (2018). The Prevention of Torture: An Ecological Approach. Cambridge: Cambridge University Press.

- Da Lomba, S (2004). The Right to Seek Refugee Status in the European Union. Oxford: Intersentia.

- De Beco, G; Quinlivan, S \& Lord, J (2019). The Right to Inclusive Education in International Human Rights Law. Cambridge: Cambridge University Press.

- Donders, Y \& Volodin, V (2007). Human Rights in Education, Science, and Culture. UNESCO.

- Eckes, C (2009). EU Counter-Terrorist Policies and Fundamental Rights: The Case of Individual Sanctions. Oxford: Oxford University Press.

- Faunce, T (2004). Pilgrims in Medicine: Conscience, Legalism and Human Rights: An Allegory of Medical Humanities, Foundational
Virtues, Ethical Principles, Law and Human Rights in Medical Personal and Professional Development. London: Brill.

- Goodman, R \& Jinks, D (2004). "How to Influence States: Socialization and International Human Rights Law". Duke Law Journal, 54 (3): 621-703.

- Guðmundur, S \& Alfreðsson, A (1999). The Universal Declaration of Human Rights: A Common Standard of Achievement. Hague: Martinus Nijhoff Publishers.

- Hakonssen, K (1996). Natural Law and Moral Philosophy: From Grotius to the Scottish Enlightenment. Cambridge: University Press.

- Heijden, B \& Tahzib-Lie, B (1998). Reflections on the Universal Declaration of Human Rights: A Fiftieth Anniversary Anthology. Hague: Martinus Nijhoff Publishers.

- Hochstrasser, T (2000). Natural Law theories in the Early Enlightenment. Cambridge: University Press.

- Hohmann, J \& Weller, M (2018). The UN Declaration on the Rights of Indigenous Peoples: A Commentary. Oxford: University Press.

- Hugo, G (2002). The Rights of war and Peace. Vol 1, Hague: Liberty Fund.

- Keane, D \& McDermott, Y (2012). The Challenge of Human Rights: Past, Present and Future. London: Edward Elgar.

- Kippenberg, H; Kuiper, Y \& Sanders, A (2012). Concepts of Person in Religion and Thought. Berlin: Mouton de Gruyter.

- Lawson, E \& Lou Bertucci, M (1996). Encyclopedia of Human Rights. London: Taylor \& Francis.

- Loveless, S \& Holman, T (2007). The Family in 
the New Millennium: The Place of Family in Human Society. London: Praeger.

- Mansbach, R (2012). Introduction to Global Politics. $2^{\text {nd }}$ ed. London and New York: Routledge Taylor and Francis Group.

- Marias, J (1967). History of Philosophy. New York: Dover Publications.

- McCrudden, C (2015). Human Rights: Law, Politics, And Philosophy. Michigan: University of Michigan Law School.

- Menendez, A (2006). Arguing Fundamental Right. Netherland: Springer.

- Miguelángel, V; Philani, M \& Wilkins, A (2020). The Global Politics of Human Rights: Bringing the Universal Declaration of Human Rights. New York: UNISA.

- Modrzejewski, B (2012). Law Books. Bialystok: Wydawnictwo Temida.

- Morsink, J (1996). The Universal Declaration of Human Rights: Origins, Drafting, and Intent. Pennsylvania: University of Pennsylvania Press.

- Nolan, C (2015). Ethics and Statecraft: The Moral Dimension of International Affairs. Denver: ABC-CLIO.

- Oakley, F (2005). Natural Law, Laws of Nature, Natural Rights: Continuity and Discontinuity in the History of Ideas. New York - London: Continuum.

- Reidar, M \& Schaffer, J (2017). Moral and Political Conceptions of Human Rights: Implications for Theory and Practice. Cambridge: University Press.

- Riedel, E (2006). Social Security as a Human Right. London: Springer.

- Sharma, A (2010). Universal Declaration of Human Rights and Indian Law. New Delhi: PHI Learning.
- Sharma, A (2011). Problematizing Religious Freedom. London: Springer.

- Spaak, T (2014). A Critical Appraisal of Karl Olivecrona's Legal Philosophy. Switzerland: Springer.

- Sweet, W (2003). Philosophical Theory and the Universal Declaration of Human Rights. Ottawa: University of Ottawa Press.

- Takemura, H (2008). International Human Right to Conscientious Objection to Military Service and Individual Duties to Disobey Manifestly Illegal Orders. London: Springer.

- Tierney, B (1997). The Idea of Natural Rights: Studies on Natural Rights, Natural Law and Church Law, 1150-1625. Atlanta: Scholars Press.

- Tomuschat, C (2003). Human Rights: Between Idealism and Realism. Oxford: Oxford University Press.

- Weissbrodt, D \&, Vega, C (2007). International Human Rights Law: An Introduction. Pennsylvania: University of Pennsylvania Press.

- Wodon, Q (2001). Attacking Extreme Poverty: Learning from the Experience of the International Movement ATD Fourth World. Vol 23, Washington: World Bank Technical Paper.

- Wronka, J (1998). Human Rights and Social Policy in the $21^{\text {st }}$ Century. US: University Press of America.

- Zol-Ein, P (2011). Basis of International General Law. $7^{\text {th }}$ ed. Tehran: Political \& International Office Publishing. (Persian)

- Zolo, D (2010). Humanitarian Militarism?. Oxford: Oxford University Press.

- Zuckert, M (1997). "Do Natural Rights Derive from Natural Law?". Harvard Journal of Law and Public Policy, 64(3): 389-406. 